\title{
Performances of an Interleaved High Step-Up Converter with Different Soft-Switching Snubbers for PV Energy Conversion Applications
}

\author{
Sheng-Yu Tseng, Hung-Yuan Wang, and Chih-Yang Hsu \\ Department of Electrical Engineering, Chang-Gung University, 259 Wen-Hwa 1st Road, Kwei-shan, Taoyuan 33302, Taiwan \\ Correspondence should be addressed to Sheng-Yu Tseng; sytseng@mail.cgu.edu.tw
}

Received 5 July 2013; Revised 12 September 2013; Accepted 22 October 2013

Academic Editor: Wayne A. Anderson

Copyright (C) 2013 Sheng-Yu Tseng et al. This is an open access article distributed under the Creative Commons Attribution License, which permits unrestricted use, distribution, and reproduction in any medium, provided the original work is properly cited.

\begin{abstract}
This paper proposes an interleaved high step-up converter with different soft-switching snubbers for PV energy conversion applications. For the high step-up converter, interleaved and coupled-inductor technologies are used to reduce output ripple current and increase output power level. Simultaneously, two types of snubbers, a single-capacitor snubber and boost type snubber, are introduced separately into the discussed converters for comparing their performances of conversion efficiency and switching losses. For drawing maximum power from the PV arrays, a perturbation-and-observation method realized with the microcontroller is adopted to achieve maximum power point tracking (MPPT) algorithm and power regulating scheme. Finally, two prototypes of the interleaved coupled-inductor boost converter with a single-capacitor snubber and with boost type snubber are implemented, respectively. The experimental results obtained are used to verify and compare the performances and feasibilities of the discussed converters with different snubbers in PV conversion applications. The experimental results show that the proposed system is suitable for PV energy conversion applications when the duty ratios of switches of the converter are less than 0.5.
\end{abstract}

\section{Introduction}

In recent years, in order to offer enough energy to maintain the economic development of the world, one of the solutions is the solar energy which is a totally inexhaustible and completely clear energy source. However, due to the instability and intermittent characteristics of solar energy, photovoltaic (PV) power conversion systems with power converter and maximum power tracking algorithms are needed to convert solar energy into electrical energy and provide stable power output. With the rapid growth of power electronics techniques, the conversion efficiency of PV power conversion system has been increased obviously $[1,2]$. Recently, PV power conversion systems are well recognized and widely used in electric power conversion system, such as $\mathrm{PV}$ power generation for grid connection, $\mathrm{PV}$ vehicle constriction, battery charger, water pumping, and satellite power conversion system.

To extract power from PV arrays, power converter is used in PV power conversion systems. In order to obtain the maximum power from $\mathrm{PV}$ arrays and thus increase utility rate of PV arrays, switching-mode converter must be operated at the maximum power point (MPP) of PV arrays, resulting in its output voltage without keeping in the desired dc constant voltage. Therefore, a switching-mode one with battery source in parallel is used for keeping the output voltage in the desired dc constant voltage, as shown in Figure 1(a). In Figure 1(a), $\mathrm{dc}$ voltages provided by the proposed PV power conversion system can be supplied to dc loads of $\mathrm{dc} / \mathrm{ac}$ inverters for grid-connected power conversion system [3-8] and $\mathrm{dc} / \mathrm{dc}$ converter for dc load [9-13]. In grid-connected power conversion system applications, control of power converters has to be taken into consideration. In [4], three different control topologies have been proposed according to the number of power processing stages. Since the multistage topology, as shown in Figure 1(b), possesses a better control performance of each DC/DC converter, it is adopted in the proposed $\mathrm{PV}$ power conversion system. Therefore, the PV power conversion system consists of a switching-mode converter for maximum power point tracking (MPPT) of $\mathrm{PV}$ arrays and a 


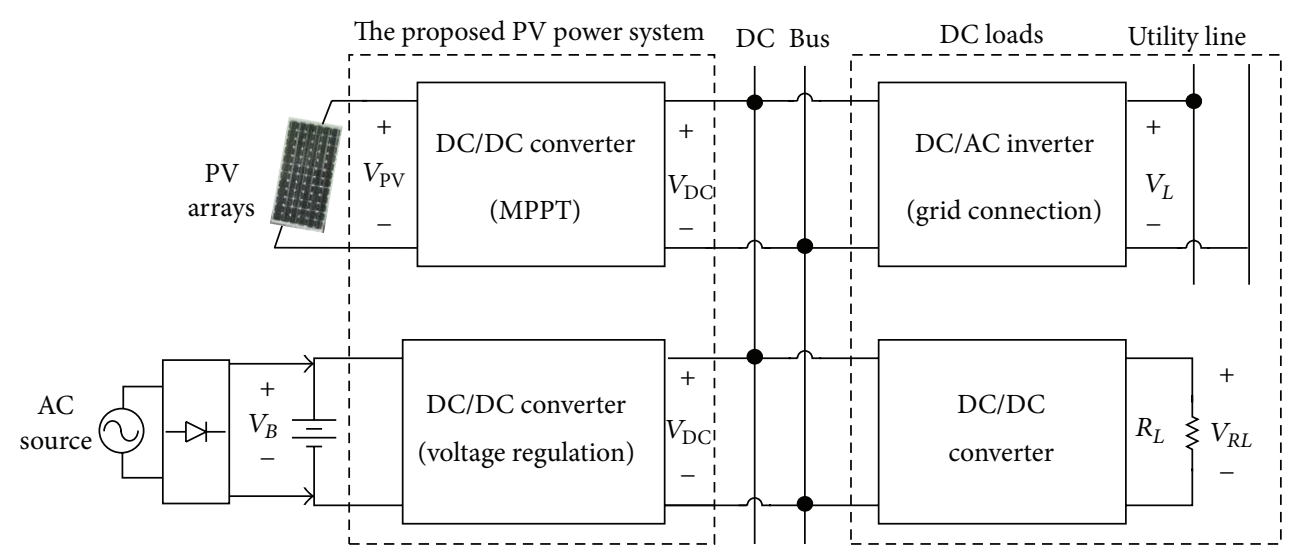

(a)

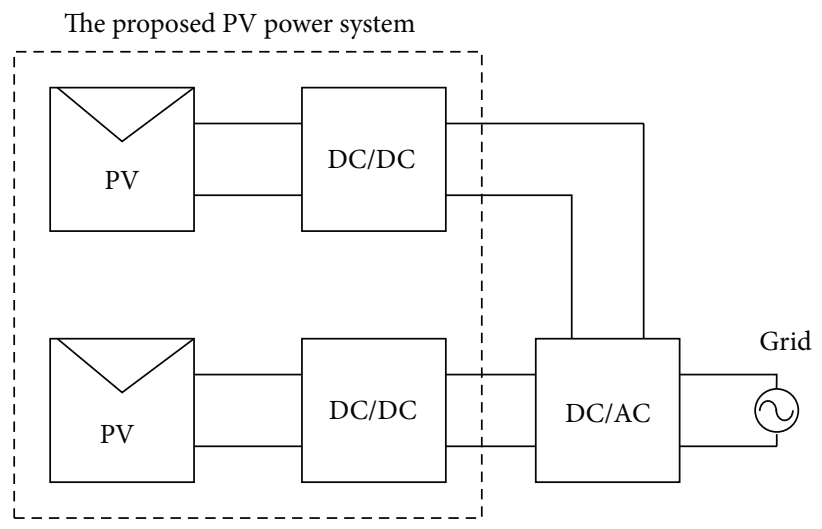

(b)

FIGURE 1: Block diagram of PV power conversion system for (a) DC load applications and (b) grid connection.

switching-mode converter for voltage regulation of dc load under the control of multistage topology.

In the MPPT algorithm research, several MPPT algorithms have been proposed [14-23]. Some of the popular MPPT algorithms are constant voltage method $[14,15]$, system oscillation method $[16,17]$, ripple correlation method [18], $\beta$ method [19], incremental conductance method [20], and perturbation-and-observation method [21-23]. Under the consideration of simplicity and easy implementation, the perturbation-and-observation method is adopted and used in the proposed PV power conversion system.

For $\mathrm{PV}$ arrays, since output voltage $V_{\mathrm{PV}}$ of the $\mathrm{PV}$ arrays is in a low voltage level, the DC/DC converter with a higher step-up voltage ratio is needed [24-28]. In [24], the voltage-fed converters are not the optimal candidates for high step-up applications because they usually have a buck type configuration and (or) LC filter in the secondary rectification circuits. With this circuit structure, it results in a large transformer turns ratio, which makes the transformer design complex and leads to a large leakage inductance. Compared with the voltage-fed converters, the current-fed converters [25-27] and the coupled-inductor converters [28] are preferable choices for high voltage conversion ratio applications. Although the current-fed converters are adopted in the PV power system, they are also used as a voltage doubler or multiplier to increase the step-up voltage ratio. When the converters adopt the voltage doubler or multiplier, capacitors of the voltage doubler must be special capacitors with a low equivalent series resistance (ESR), high current ripple rating (CRR), and high operational bandwidth. Therefore, it is only suitable for using in the low power level applications. In [28], a high step-up converter achieved by a coupled inductor is presented. Compared with converters using an isolation transformer to obtain the high step-up voltage ratio, the one using the coupled inductor has a more simple winding structure and higher coupling coefficient. It not only reduces inductor currents to ensure a lower conduction loss but also decreases leakage inductance to attain a lower switching loss. Therefore, the boost converter with the coupled inductor is used in the proposed system.

For further increasing the power capability of the converter, the boost converter used in the proposed system is constructed in an interleaved manner [29-33]. Moreover, PWM ICs with two gate signals are used to drive switches of the interleaved converter. Since the voltage fed type of input sources are used in the converters and it is difficult to obtain a special PWM IC with duty ratio greater than $0.5(\geq 0.5)$, PWM ICs with duty ratio within 0.5 are used to control the switches in the discussed boost converters. Therefore, the operation of the proposed converter is constrained under duty ratio of 0.5 . 
When a coupled inductor boost converter is used in the PV power conversion system, the energy trapped in the leakage inductor of coupled inductor not only increases voltage stresses but also induces switching lossless of switches in the converter, significantly. In order to solve these problems, several methods have been proposed [34-36]. In [34], a resistorcapacitor-diode (R-C-D) snubber is used to alleviate voltage stresses of switches by dissipating the energy trapped in the leakage inductor through the resistor, reducing the conversion efficiency of the converter. Therefore, a passive lossless circuit proposed in [35] is adopted to reduce voltage spike across switches. Its schematic diagram with the interleaved manner is shown in Figure 2. Although converters with a passive lossless circuit can improve conversion efficiency, active switches are still operated in hard switching at turnon transition. In [36], an active clamp circuit is introduced to achieve zero-voltage switching (ZVS) and increased its conversion efficiency. However, the disadvantage of the active clamp circuit is that it is difficult to implement soft-switching features at light load for the boost converter. In order to solve this problem, a boost type snubber is inserted into the active clamp boost converter with coupled inductor, as shown in Figure 3. It can improve conversion efficiency of the boost converter at light load, significantly. Due to the complexity of circuit structures shown in Figures 2 and 3, they are, respectively, simplified by [37] and [38] and are shown in Figures 4(a) and 4(b). In this paper, performance comparisons between the discussed converters with the single-capacitor snubber and with boost type snubber are proposed.

\section{Control Algorithm of the Proposed Converter}

When a switching-mode $\mathrm{dc} / \mathrm{dc}$ converter is adopted as their power processor for extracting power from PV arrays and converting the power into dc voltage supplied to dc loads, a proper power management system for managing the power is needed in the PV power conversion system. In the following, the circuit topology of the proposed converter power conversion system, MPPT algorithm, and power management are described.

2.1. Circuit Topology of the Proposed Converter. The proposed $\mathrm{PV}$ power conversion system uses PV arrays as one of its power sources. For increasing the utility rate of the PV arrays, the PV arrays have to be operated on their maximum power. Therefore, as shown in Figure 5, a PV power conversion system constructed of a switching-mode converter with PV array sources, a switching-mode converter with battery source, and a controller is proposed. In the proposed PV power system, the two dc/dc converters are realized by an interleaved coupled-inductor boost converter with singlecapacitor snubber shown in Figure 4(a). The one with PV arrays source uses MPPT control algorithm for extracting the maximum power from PV arrays. The other with battery source uses voltage regulation control method to regulate powers between PV arrays and loads and to generate a constant output voltage supplied to dc loads. As shown in Figure 5, controller constructed by MPPT unit, power management unit, and PWM IC unit is used to control the $\mathrm{dc} / \mathrm{dc}$ converter with PV array source for determining the MPP of PV arrays by the perturbation-and-observation method described in [21-23]. There are two signals generated by the power management, control signals $M_{1}$ and $S_{P}$. Control signal $M_{1}$ is used to regulate output powers of switching-mode converter with MPPT control algorithm. Control signal $S_{P}$ is generated according to the relationships between the maximum power $P_{\mathrm{PV}(\max )}$ of $\mathrm{PV}$ arrays and power of load $P_{L}$. Based on the control signal $S_{P}$ and the output $V_{O}$, PWM IC unit generates control signal $M_{2}$ with voltage regulation control method for obtaining constant output voltage. Protections are considered and implemented by microcontroller. The protections include over-current, over-voltage, and over-temperature protections of the two converters and undercharge of battery. Therefore, the proposed PV power conversion system can be used to achieve the optimal utility rate of PV arrays.

2.2. Power Management. The power of PV arrays is supplied to the load through the proposed interleaved boost converter. The power management of the proposed power conversion system is implemented by a microcontroller and is used to regulate the power of PV arrays and output power. According to relationships among the powers of $P_{\mathrm{PV}}, P_{V B}$, and $P_{L}$, operational modes of power management can be divided into 8 modes and are illustrated in Table 1 . Power $P_{\mathrm{PV}}$ is output power of switching-mode converter with PV arrays as its power source, $P_{V B}$ is that of switching-mode converter with battery as its power source, and $P_{L}$ is power of load. Moreover, " 1 " represents that the power is generated by switching-mode converter or is required by load, while " 0 " represents that the power is not generated by switching-mode converter or is not required by load. According to the operational modes illustrated in Table 1, PV power conversion system is shut down in operational modes of I, II, III, V, and VII. Therefore, operational modes IV, VI, and VIII are described as follows.

2.2.1. Operational Mode IV. In mode IV, the switching-mode converter with battery is used to supply power to the load. Once the condition of $P_{L}>P_{V B(\max )}$ is reached or energy stored in battery is completely discharged, the proposed converter is shut down.

2.2.2. Operational Mode VI. In mode VI, the switching-mode converter with $\mathrm{PV}$ arrays as its power source is used to supply power to load. When power of $P_{\mathrm{PV}(\max )}$ is equal to or greater than that of $P_{L}$, power curve of PV arrays follows that of load. Once $P_{\mathrm{PV}(\max )}<P_{L}$, the proposed converter is shut down.

2.2.3. Operational VIII. When PV power conversion system is operated in mode VIII, the interleaved boost converter supplies power to load, as shown in Figure 6. During this operational mode, $\left(P_{\mathrm{PV}(\max )}+P_{B(\max )}\right)$ must be equal to or greater than $P_{L}$. If $\left(P_{\mathrm{PV}(\max )}+P_{B(\max )}\right)<P_{L}$, the proposed $\mathrm{PV}$ power conversion system is shut down. When $\left(P_{\mathrm{PV}(\max )}+\right.$ $\left.P_{B(\max )}\right) \geq P_{L}$, the operational condition can be further 


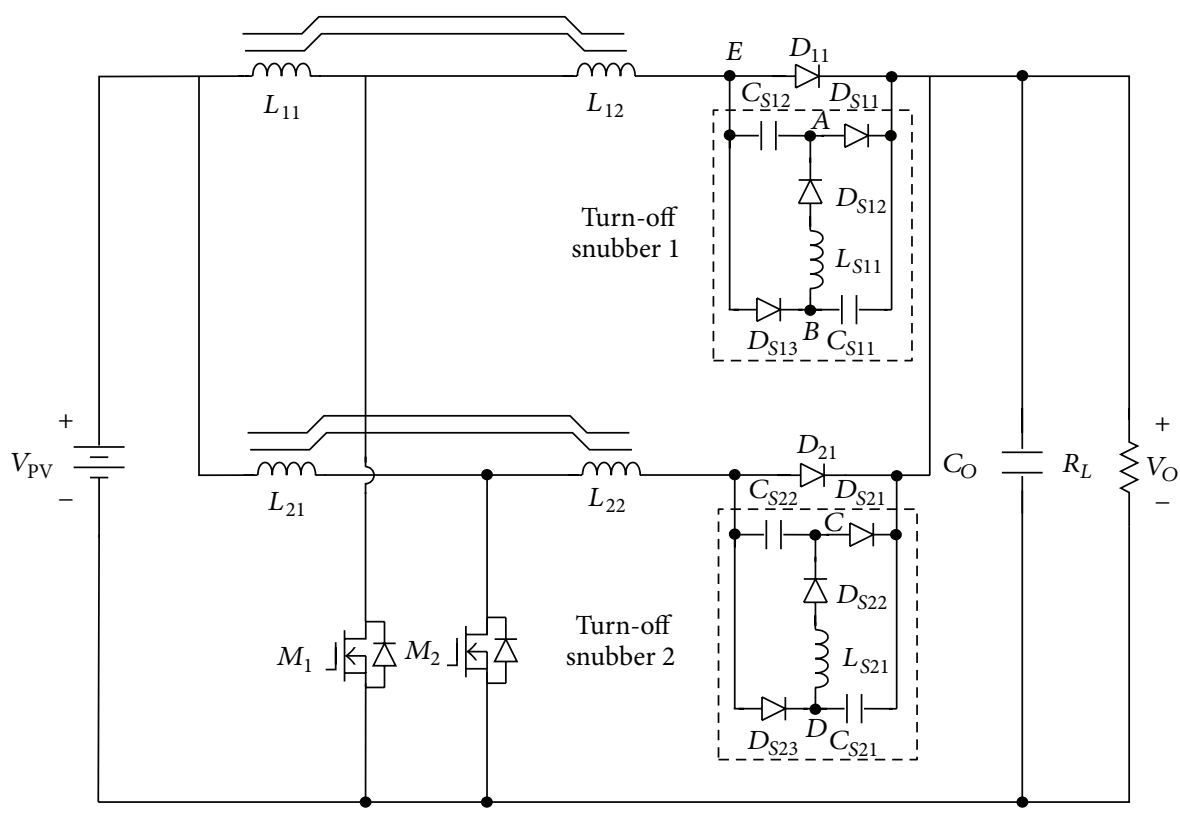

FIGURE 2: Schematic diagram of interleaved coupled-inductor boost converter with lossless turn-off snubber.

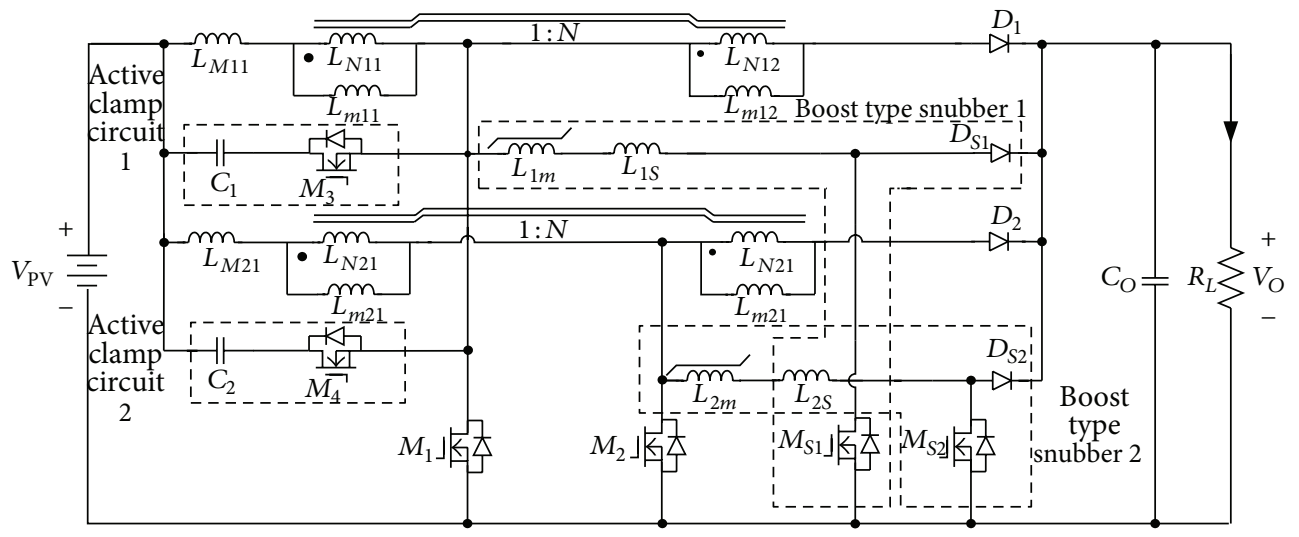

FIGURE 3: Schematic diagram of interleaved coupled-inductor boost converter with boost type snubber.

TABLE 1: Operational conditions of PV arrays for the proposed converter.

\begin{tabular}{lcccc}
\hline $\begin{array}{l}\text { Operational } \\
\text { modes }\end{array}$ & \multicolumn{2}{c}{ Power states } & Operational conditions of PV \\
& $P_{\mathrm{PV}}$ & $P_{\mathrm{VB}}$ & $P_{L}$ & power conversion system \\
\hline I & 0 & 0 & 0 & Shutdown \\
II & 0 & 0 & 1 & Shutdown \\
III & 0 & 1 & 0 & Shutdown \\
IV & 0 & 1 & 1 & Working \\
V & 1 & 0 & 0 & Shutdown \\
VI & 1 & 0 & 1 & Working \\
VII & 1 & 1 & 0 & Shutdown \\
VIII & 1 & 1 & 1 & Working \\
\hline
\end{tabular}

divided into two cases: $P_{\mathrm{PV}(\max )} \geq P_{L}$ and $P_{\mathrm{PV}(\max )}<P_{L}$. In the following, the two cases are briefly described.
(1) $P_{P V(\max )} \geq P_{L}$ and $P_{B(\max )}<P_{L}$. When $P_{\mathrm{PV}(\max )} \geq P_{L}$ and $P_{B(\max )}<P_{L}$, the switching-mode converter with battery source is shut down, causing the output power $P_{\mathrm{PV}}$ of $\mathrm{PV}$ arrays to be equal to $P_{L}$, as shown in Figure 6(a). Hence, the switching-mode converter with PV arrays source is operated in voltage regulation mode to supply the desired dc voltage to load.

(2) $P_{P V(\max )}<P_{L}$ and $P_{B(\max )}<P_{L}$. When $P_{\mathrm{PV}(\max )}<P_{L}$ and $P_{B(\max )}<P_{L}$, the switching-mode converter with $\mathrm{PV}$ array source is operated at the MPP of PV arrays to extract the maximum power from the PV arrays. On the other hand, the one with battery source is used to sustain the desired dc voltage. Power curve for operational mode VIII under $P_{\mathrm{PV}(\max )}<P_{L}$ and $P_{B(\max )}<P_{L}$ is shown in Figure 6(b). From Figure 6(b), it can be seen that $P_{L}$ is the sum of $P_{\mathrm{PV}}$ and $P_{B}$. 


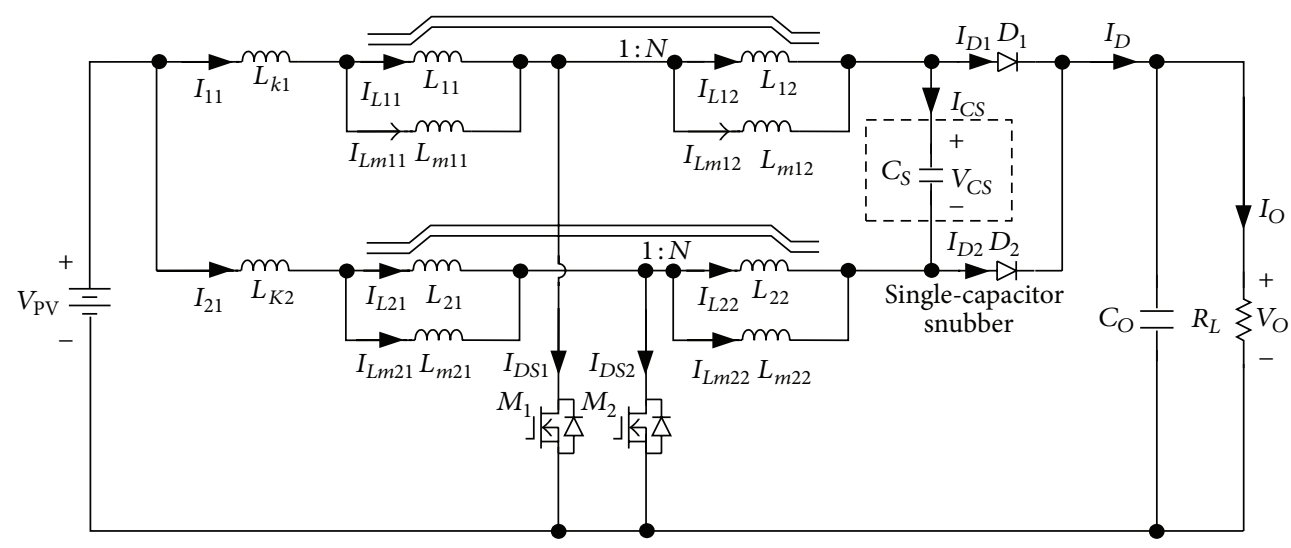

(a)

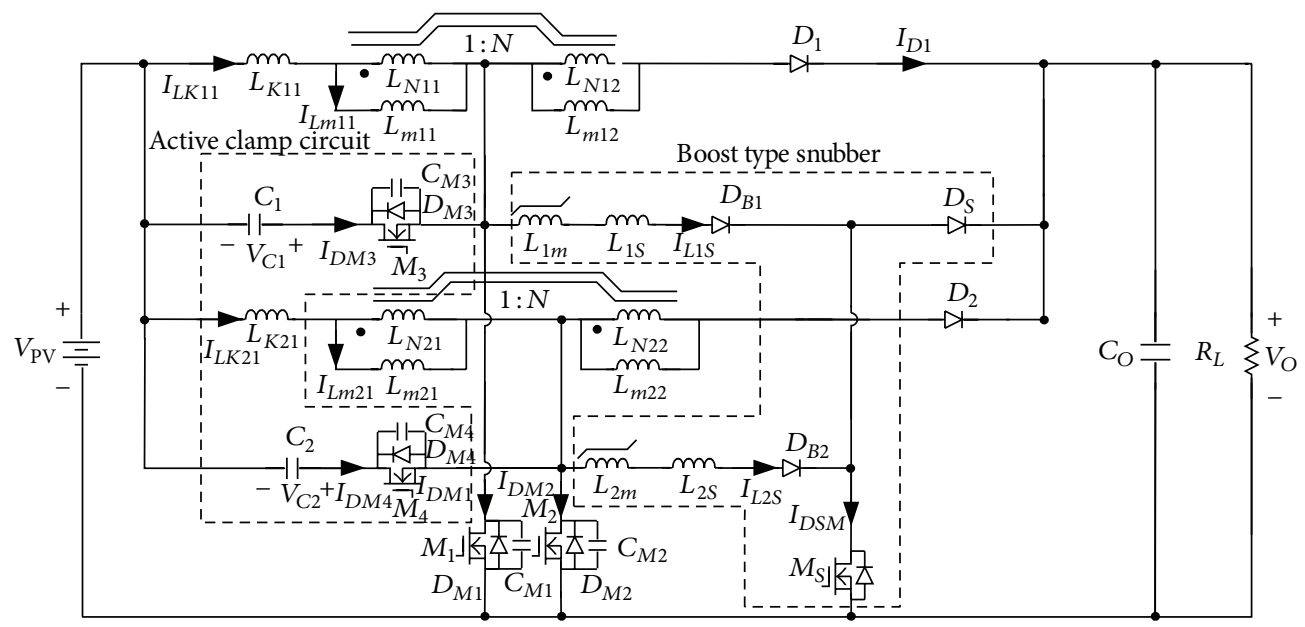

(b)

FIGURE 4: Schematic diagram of interleaved coupled-inductor boost converter (a) with a single-capacitor snubber and (b) with boost type snubber.

\section{Control Design of the Proposed PV Power Conversion System}

As shown in Figure 7, controller of the proposed power conversion system consists of two major units, the microcontroller and the PWM IC units. The microcontroller is further divided into the MPPT unit and the power management unit. In the following, functions of each block will be described briefly.

3.1. The MPPT Unit. The MPPT unit uses the perturbationand-observation method to track MPPT of PV arrays and to decide the maximum power $P_{\mathrm{PV}(\max )}$ of $\mathrm{PV}$ array, resulting in the output power of $P_{P}$ for further power management.

3.2. The Power Management Unit. In the power management unit, the maximum discharging current $I_{B(\max )}$ of battery is set for obtaining the maximum battery discharging power $P_{B(\max )}$ of $V_{B} I_{B(\max )}$. Based on the output power of MPPT unit $P_{P}$, the maximum battery discharging power, and the load power $P_{L}$ of $V_{O} I_{O}$, comparator number 1 determines the relationships between $\left(P_{\mathrm{PV}}+P_{B(\max )}\right)$ and $P_{L}$. There are two relationships to be discussed.

3.2.1. Case I: $\left(P_{P V}+P_{B(\max )}\right) \geq P_{L}$. When $\left(P_{\mathrm{PV}}+P_{B(\max )}\right) \geq$ $P_{L}$, control signal $S_{P 1}$ of comparator number 1 is in the low level, causing further comparison of $P_{P}$ and $P_{L}$ in comparator number 2. If $P_{P} \geq P_{L}$, the low level output signal $S_{1}$ of comparator number 2 makes the power selector to set the power $P_{\text {set }}$ to be equal to $P_{L}$. Once $P_{P}<P_{L}$, output signal $S_{1}$ of comparator number 2 becomes a high level and causes the power selector to set the power $P_{\text {set }}$ to be equal to $P_{P}$. Then, in the reference current block, the power $P_{\text {set }}$ and the reference voltage $V_{\text {ref }}$ are used to calculate the reference current $I_{C}$ for obtaining the current error value $\Delta I_{C}\left(=I_{C}-I_{O P}\right)$ with output current of the proposed converter with PV array source, $I_{O P}$, in the current error amplifier.

In the PWM generator of PV array, control signals $G_{1 A}$ and $G_{2 A}$ are obtained by comparing current error value $\Delta I_{C}$ with triangular wave generated by the PWM generator of PV arrays. The control signals $G_{1 A}$ and $G_{2 A}$ are used to drive 


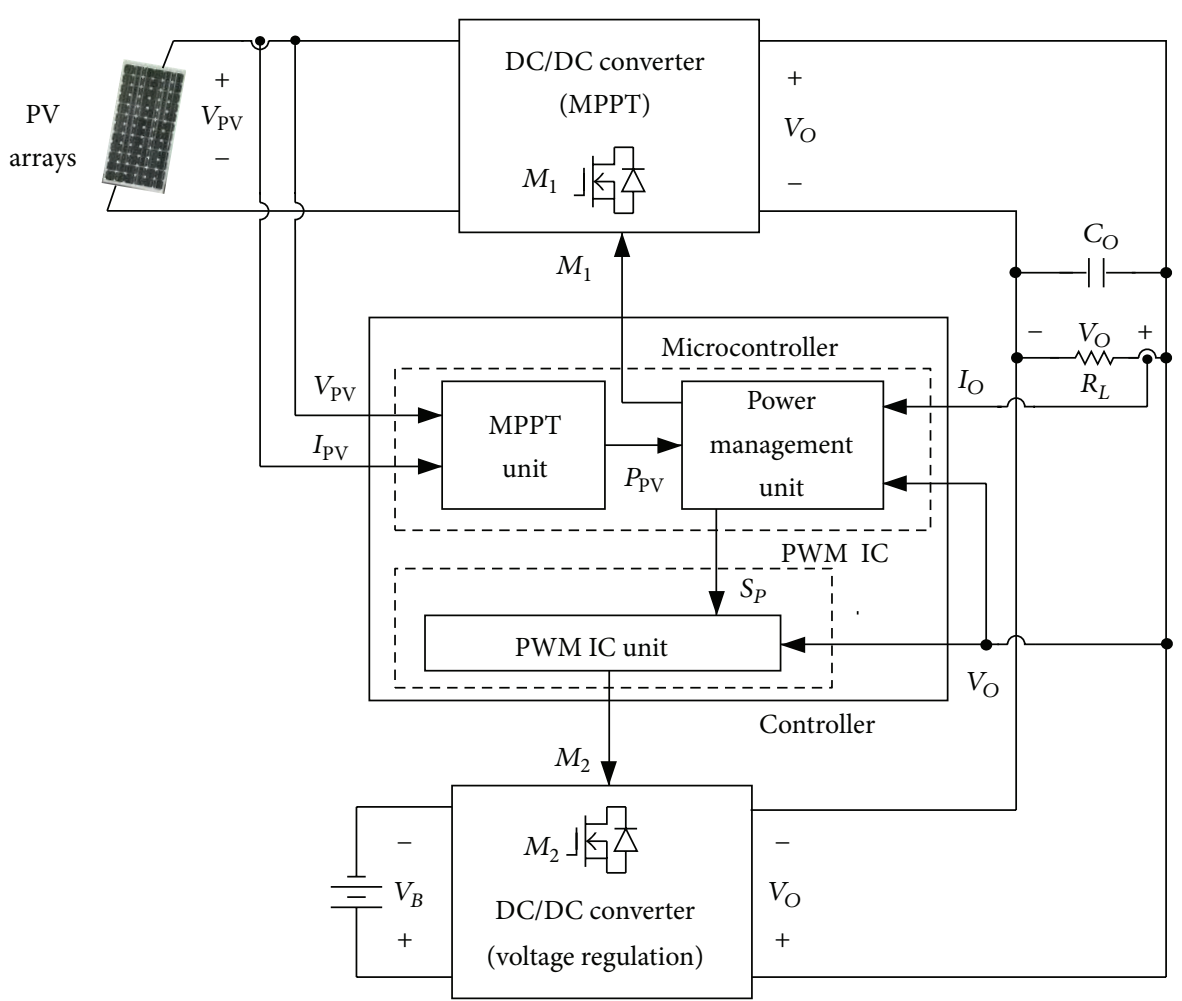

FIGURE 5: Block diagram of the proposed PV power conversion system.

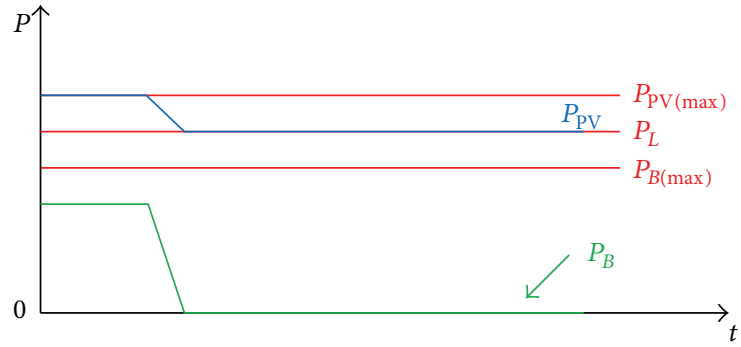

(a)

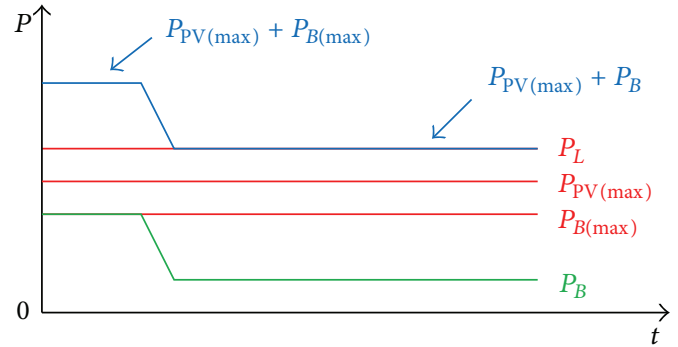

(b)

Figure 6: Plot of power curves $P_{\mathrm{PV}}, P_{B}$, and $P_{L}$ (a) under $P_{\mathrm{PV}(\max )} \geq P_{L}$ and $P_{B(\max )}<P_{L}$ and (b) under $P_{\mathrm{PV}(\max )}<P_{L}$ and $P_{B(\max )}<P_{L}$.

switches $M_{1 A}$ and $M_{2 A}$ of the proposed converter with PV array source for controlling power flowed from PV arrays to load.

3.2.2. Case II: $\left(P_{P V}+P_{B(\max )}\right)<P_{L}$. When $\left(P_{\mathrm{PV}}+P_{B(\max )}\right)<$ $P_{L}$, control signal $S_{P 1}$ of comparator \#1 is in the high level, causing both of PWM generators of PV array and battery to be shut down. The power management unit also includes functions of protection, which are over-voltage, over-current, under-voltage, and undercharge protections. As shown in Figure 7, there are six input signals to the protection controller, $V_{O(\max )}, V_{O(\min )}, I_{O(\max )}, V_{B(\max )}, I_{O}, V_{O}$, and $V_{B}$, where $V_{\mathrm{O}(\max )}$ and $V_{\mathrm{O}(\min )}$ are maximum and minimum values of output voltage, $I_{O(\max )}$ is maximum value of output current, $V_{B(\min )}$ is minimum value of battery voltage, $I_{O}$ is output current, $V_{O}$ is output voltage, and $V_{B}$ is voltage of battery.
When $V_{O} \geq V_{O(\max )}$, the proposed converter is operated in over-voltage condition, causing the output signal $S_{P 2}$ to be in a high level and shut down both of the PWM generators. Moreover, conditions of $I_{O} \geq I_{O(\max )}$ (over-current condition), $V_{O} \leq V_{O(\min )}$ (under-voltage condition), or $V_{B} \leq V_{B(\min )}$ (undercharge condition) also make signal $S_{P 2}$ to be in a high level to shut down both of the PWM generators.

3.3. The PWM IC Unit. The proposed boost converter with battery source uses lead-acid battery as its power source. In order to implement power balance among PV arrays, battery, and load and sustain a constant output voltage, a PWM IC unit is adopted. This control unit includes voltage error amplifier and PWM generator of battery. Based on the output voltage $V_{O}$ and reference voltage $V_{\text {ref }}$, the voltage error amplifier determines the voltage error value $\Delta V_{C}$ of 
The proposed boost converter with PV arrays

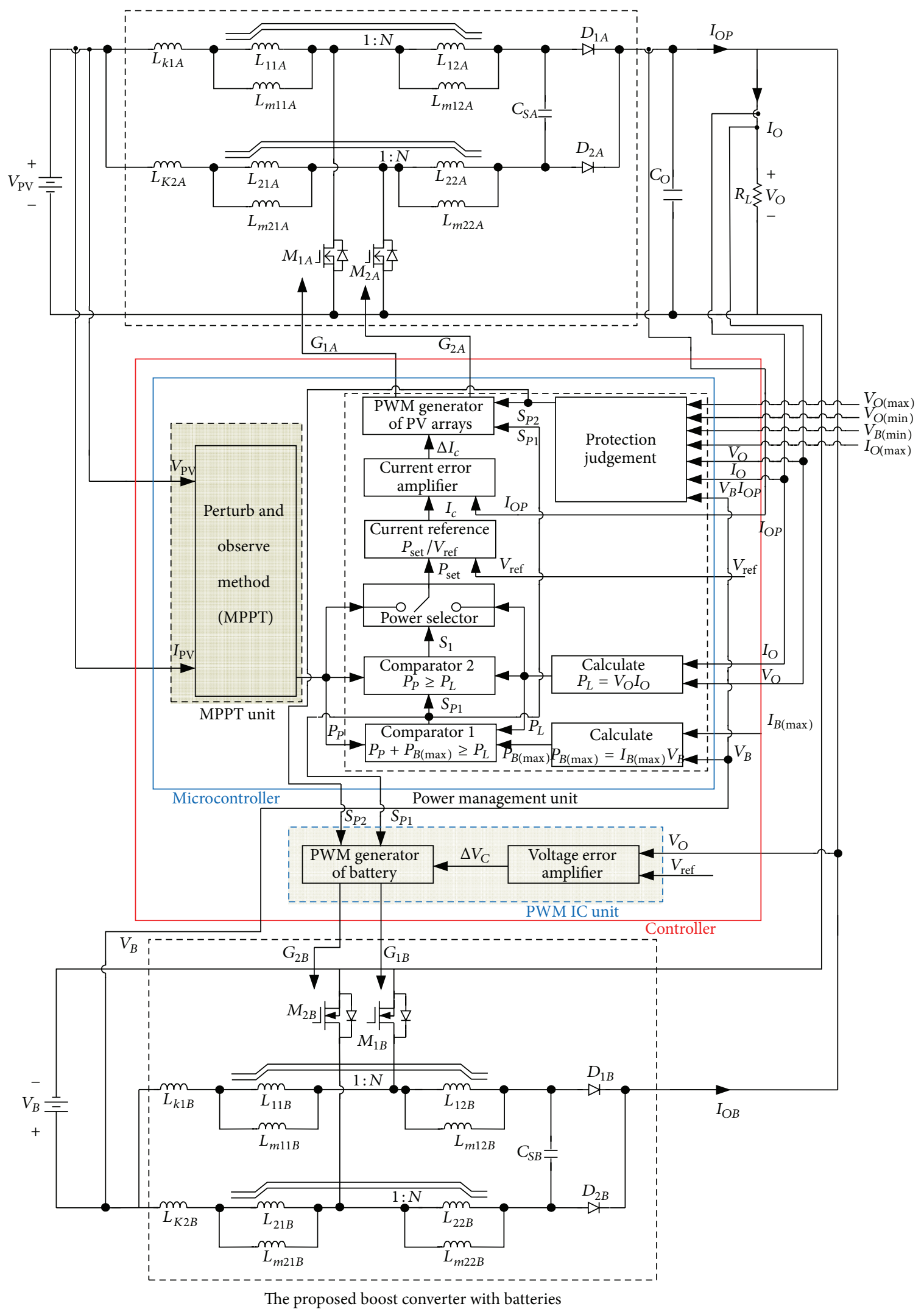

FIGURE 7: Control diagram of the proposed power conversion system with the single-capacitor snubber for PV array applications. 


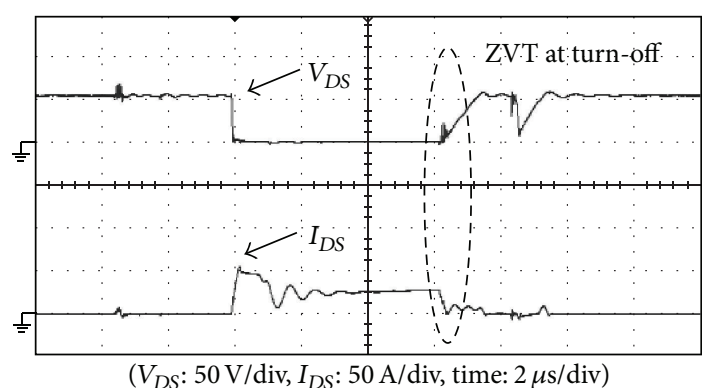

(a)

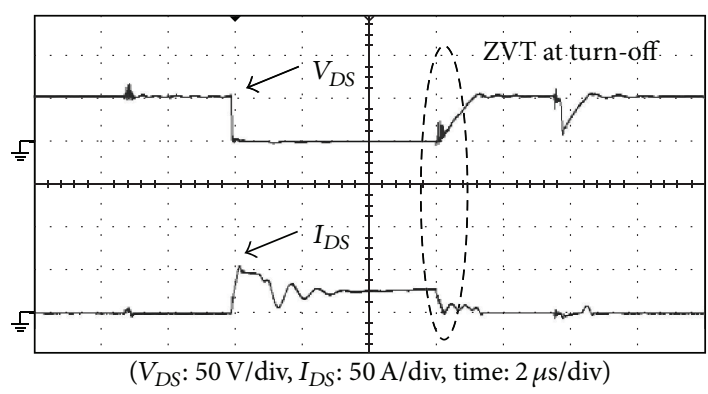

(b)

FIGURE 8: Measured voltage $V_{D S}$ and current $I_{D S}$ waveforms of (a) switch $M_{1 B}$ and (b) switch $M_{2 B}$ under $50 \%$ of full load when the proposed PV power conversion system with the single-capacitor snubber.

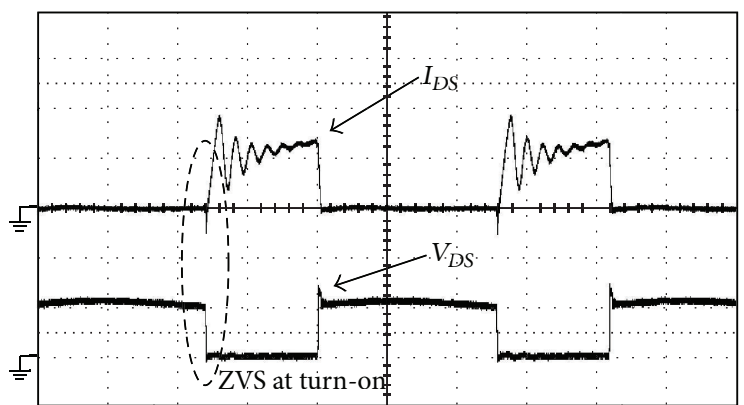

$\left(V_{D S}: 50 \mathrm{~V} /\right.$ div, $I_{D S}: 20 \mathrm{~A} /$ div, time: $5 \mu \mathrm{s} /$ div $)$

(a)

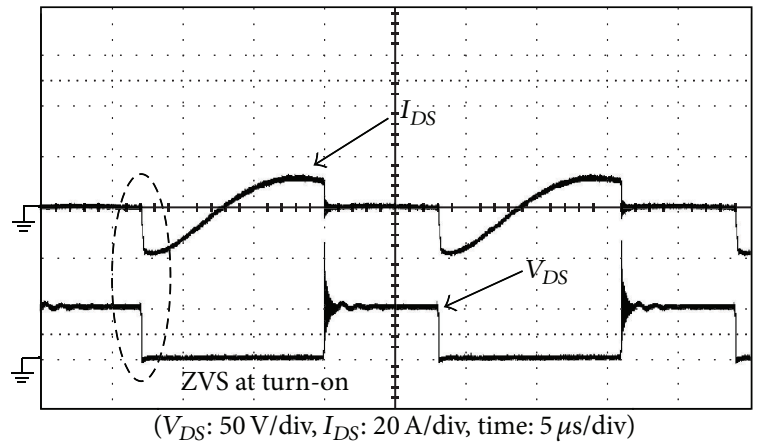

(b)

FIGURE 9: Measured voltage $V_{D S}$ and current $I_{D S}$ waveforms of (a) switch $M_{1 B}$ and (b) switch $M_{3 B}$ of the proposed converter $50 \%$ of full load when the proposed PV power conversion system with boost type snubber.

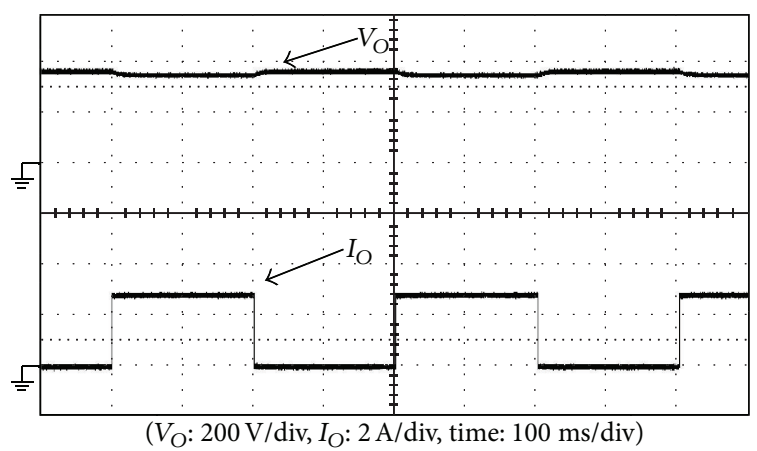

(a)

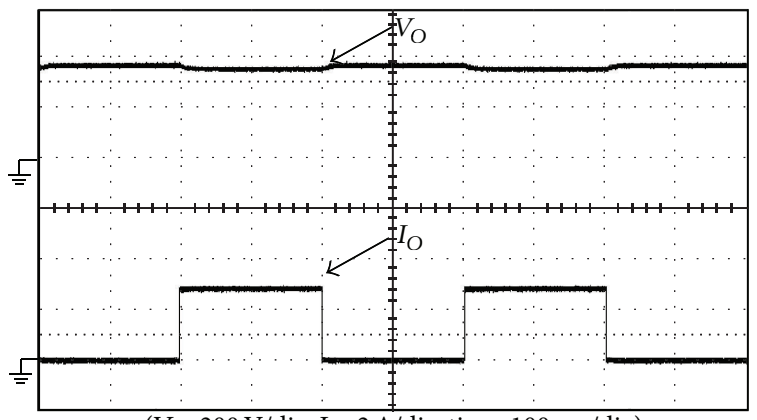

$\left(V_{O}: 200 \mathrm{~V} /\right.$ div, $I_{O}: 2 \mathrm{~A} /$ div, time: $100 \mathrm{~ms} /$ div $)$

(b)

FIGURE 10: Output voltage $V_{O}$ and output current $I_{O}$ under step-load changes between $0 \%$ and $100 \%$ of the full load of the active clamp interleaved boost converter (a) with the single-capacitor snubber and (b) with the boost type snubber.

$\left(V_{\text {ref }}-V_{O}\right)$. The voltage error value $\Delta V_{C}$ is then sent to PWM generator of battery to be compared with triangle wave generated by PWM IC for obtaining PWM signals $G_{1 B}$ and $G_{2 B}$. Signals $G_{1 B}$ and $G_{2 B}$ are used to control switches $M_{1 B}$ and $M_{2 B}$ for regulating powers between PV arrays and load. Similarly, the PWM generator of battery can be shut down either by signals $S_{P 1}$ or $S_{P 2}$.

\section{Experimental Results}

To verify performances of the proposed PV power conversion system, dc/dc converters realized by the interleaved coupledinductor boost converter with single-capacitor snubber and boost type snubber for generating $\mathrm{dc}$ voltage of $400 \mathrm{~V}$ for dc load applications were implemented with the following specifications.

(A) The proposed boost converter with PV arrays is as follows.

(i) Input voltage $V_{\mathrm{PV}}: 34 \sim 42 \mathrm{~V}$ (PV arrays).

(ii) Output voltage $V_{\mathrm{O}}: 400 \mathrm{~V}_{\mathrm{dc}}$.

(iii) Output maximum current $I_{\mathrm{OP}(\max )}: 3 \mathrm{~A}$.

(iv) Output maximum power $P_{\mathrm{PV}(\max )}: 1.2 \mathrm{~kW}$.

(B) The proposed boost converter with battery is as follows. 


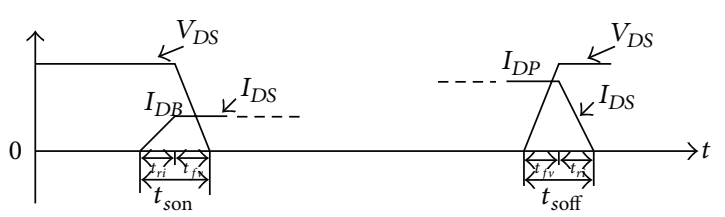

(a)

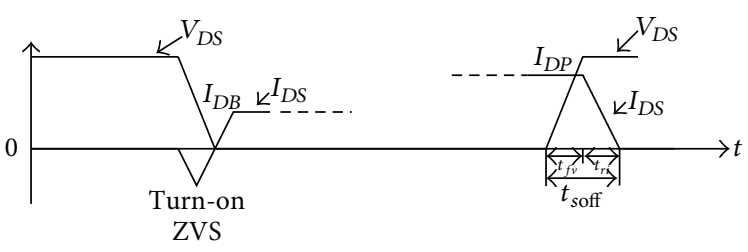

(b)

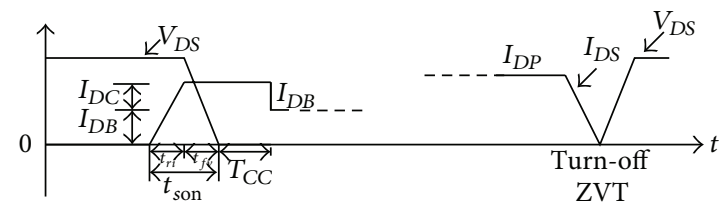

(c)

FIGURE 11: Conceptual current and voltage waveforms of switch in the interleaved boost converter (a) with hard-switching circuit, (b) with boost type snubber, and (c) with single-capacitor snubber.

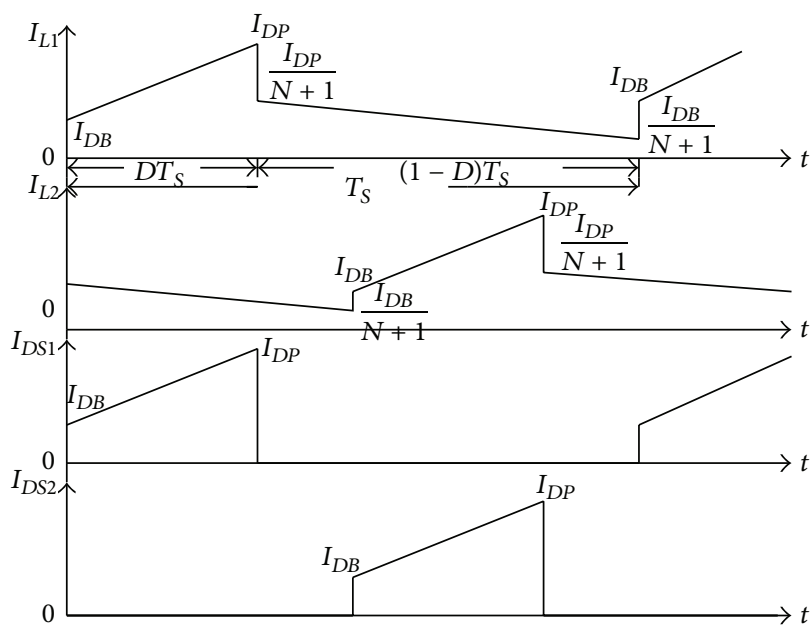

(a)

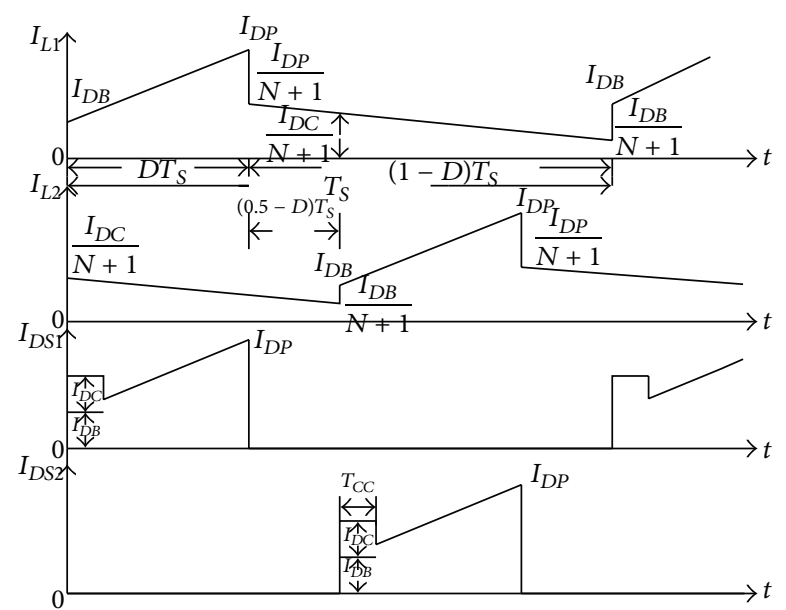

(b)

FIGURE 12: Conceptual current waveforms of switches and inductors in the interleaved boost converter (a) with hard-switching circuit and (b) with single-capacitor snubber.

(i) Input voltage $V_{B}: 44 \sim 54 \mathrm{~V}_{\mathrm{dc}}$ (4 sets of $12 \mathrm{~V}$ battery connected in series).

(ii) Output voltage $V_{\mathrm{O}}: 400 \mathrm{~V}_{\mathrm{dc}}$.

(iii) Output maximum current $I_{\mathrm{OB}(\max )}: 3 \mathrm{~A}$.

(iv) Output maximum power $P_{B(\max )}: 1.2 \mathrm{~kW}$.

According to designs and specifications of the proposed boost converters with the single-capacitor snubber, components of power stages in the proposed one are determined as follows.

(i) Switches $M_{1 A}, M_{2 A}, M_{1 B}$, and $M_{2 B}$ : IRFP260N.

(ii) Diodes $D_{1 A}, D_{2 A}, D_{1 B}$, and $D_{2 B}$ : HFA08TB120 $\times 2$ (connected in series).

(iii) Coupled inductors $L_{m 11}, L_{m 21}: 30 \mu \mathrm{H}$.

(iv) Leakage inductors of coupled inductors $\left(L_{m 11}, L_{m 12}\right)$ and $\left(L_{m 21}, L_{m 22}\right): 1.1 \mu \mathrm{H}$. (v) Cores of coupled inductors $\left(L_{m 11}, L_{m 12}\right)$ and $\left(L_{m 21}\right.$, $\left.L_{m 22}\right)$ : EE-55.

(vi) Turns ratio $N: 20$.

Similarly, components of power stages in the proposed boost converters with boost type snubber are determined as follows.

(i) Switches $M_{1 A} \sim M_{S A}$ :IRFP260N.

(ii) Switches $M_{1 B} \sim M_{S B}$ : IRFP260N.

(iii) Diodes $D_{1 A}, D_{2 A}, D_{1 B}$, and $D_{2 B}$ : HFA08TB120 $\times 2$ (connected in series).

(iv) Diodes $D_{B 1 A}, \quad D_{B 2 A}, \quad D_{B 1 B}, D_{B 2 B}$, and $D_{s}$ : HFA08TB120 $\times 2$ (connected in series).

(v) Coupled inductors $L_{m 11}, L_{m 21}: 30 \mu \mathrm{H}$.

(vi) Leakage inductors of coupled inductors $\left(L_{m 11}, L_{m 12}\right)$ and $\left(L_{m 21}, L_{m 22}\right): 1.1 \mu \mathrm{H}$. 


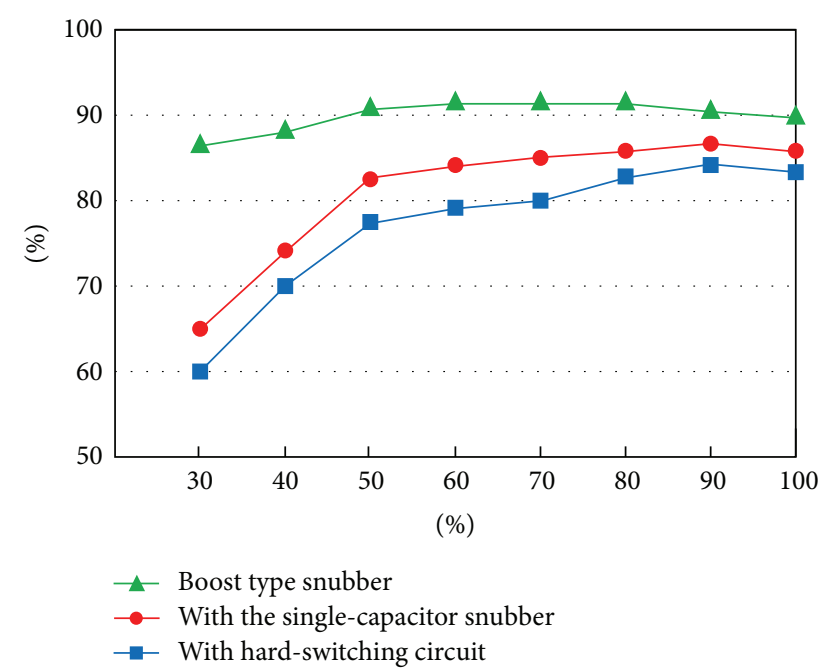

Figure 13: Comparison the efficiencies between the discussed interleaved boost converter with hard switching, with the single-capacitor snubber, and with boost type snubber from light load to heavy load.

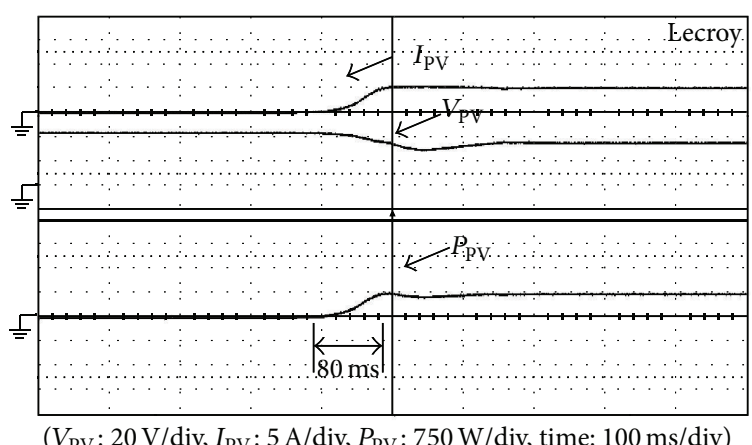

FIGURE 14: Measured voltage $V_{\mathrm{PV}}$, current $I_{\mathrm{PV}}$, and power $P_{\mathrm{PV}}$ waveforms of the converter with PV arrays source and with the singlecapacitor snubber under $P_{\mathrm{PV}(\max )}=750 \mathrm{~W}$.

(vii) Cores of coupled inductor $\left(L_{m 11}, L_{m 12}\right)$ and $\left(L_{m 21}\right.$, $\left.L_{m 22}\right): \mathrm{EE}-55$.

(viii) Turns ratio $N: 20$.

(ix) Inductors $L_{1 s}, L_{2 s}: 3 \mu \mathrm{H}$.

(x) Cores of inductors $L_{1 s}, L_{2 s}:$ DR28X12.

(xi) Capacitors $C_{1 A}, C_{2 A}, C_{1 B}, C_{2 B}: 15 \mu \mathrm{F}$.

To verify performances of the high step-up converter applied to the PV power system, some of important comparisons have been made and listed in Table 2. It can be seen from Table 2 that the proposed boost converter with the singlecapacitor snubber has less component counts, lower cost, and easier control circuit, while the proposed one with boost type snubber has more component counts, higher cost, more complexity control circuit, and high conversion efficiency. They are suitable for middle or high power level applications. In addition, although the high step-up converters proposed

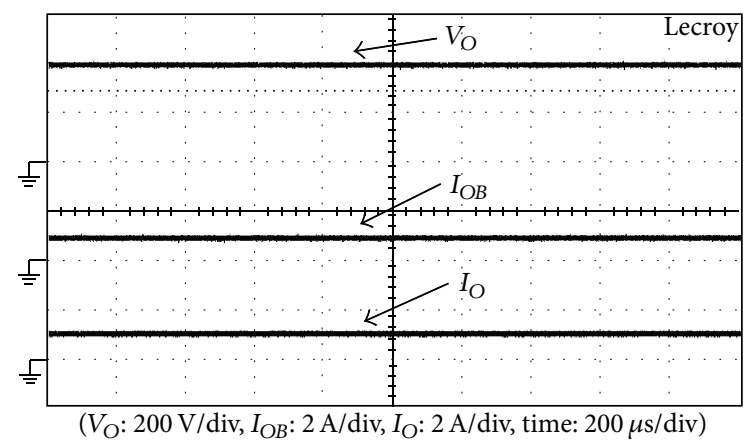

FIGURE 15: Measured voltage $V_{O}$, current $I_{\mathrm{OB}}$, and $I_{\mathrm{O}}$ waveforms of the proposed PV power conversion system using the single-capacitor snubber operated in mode IV under $P_{L}=350 \mathrm{~W}$.

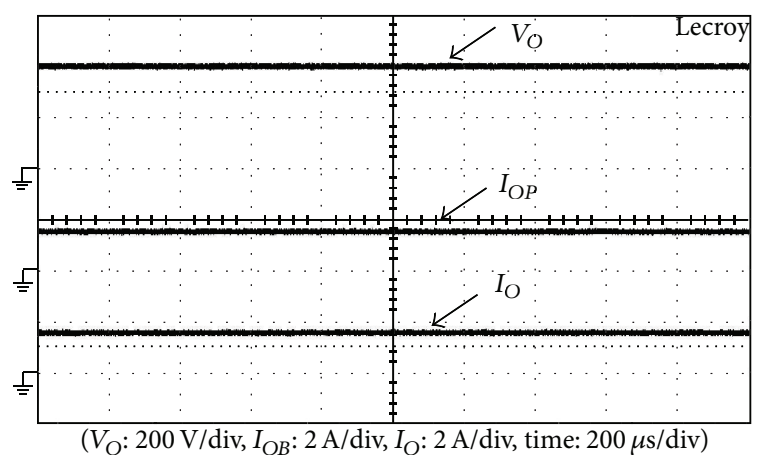

FIGURE 16: Measured voltage $V_{O}$, current $I_{\mathrm{OP}}$, and $I_{\mathrm{O}}$ waveforms of the proposed PV power conversion system using the single-capacitor snubber operated in mode VI under $P_{L}=600 \mathrm{~W}$.

in $[25,27]$ have higher conversion efficiency, they are only applied to low or middle power level applications.

Moreover, hardware dimension of each DC/DC converter is about $210 \times 297 \mathrm{~mm}$. In order to verify the feasibility of the proposed boost converter with battery source, measured voltage $V_{D S}$ and current $I_{D S}$ waveforms of switches are shown in Figures 8 and 9. Figure 8 shows those waveforms of switches $M_{1 B}$ and $M_{2 B}$ under $50 \%$ of full-load condition when the proposed one adopts the single-capacitor snubber, while Figure 9 shows those waveforms of switches $M_{1 B}$ and $M_{3 B}$ under $20 \%$ of full load condition when the proposed one uses boost type snubber. Experimental results reveal that when the discussed boost converter with the single-capacitor snubber is adopted, switches can be operated with zeroswitching transition (ZVT) at turn-off transition. Switches of the discussed one with boost type snubber are operated with ZVS at turn-on transition.

To make a fair comparison, the components of the boost converter with hard-switching circuit, the single-capacitor snubber, and boost type snubber are kept the same as possible. Figure 10 shows measured output voltage $V_{O}$ and current $I_{O}$ waveforms of the boost converter with three different snubbers under step-load changes between $0 \%$ and $100 \%$ of full load with repetitive rate of $0.5 \mathrm{~Hz}$ and a duty ratio of $50 \%$. From Figure 10, it can be observed that voltage regulations of 
TABLE 2: Preliminary comparisons among the different high step-up converters for the PV power system.

\begin{tabular}{|c|c|c|c|c|}
\hline Items for comparison & $\begin{array}{l}\text { The proposed boost } \\
\text { converter with } \\
\text { single-capacitor snubber }\end{array}$ & $\begin{array}{c}\text { The proposed boost } \\
\text { converter with boost type } \\
\text { snubber }\end{array}$ & $\begin{array}{l}\text { The boost converter } \\
\text { proposed in [25] }\end{array}$ & $\begin{array}{c}\text { The high step-up } \\
\text { converter proposed in } \\
\text { [27] }\end{array}$ \\
\hline \multicolumn{5}{|l|}{ Key component counts } \\
\hline Active switch & 2 & 5 & 4 & 4 \\
\hline Passive switch & 2 & 5 & 4 & 2 \\
\hline Magnetic core & 2 & 6 & 4 & 3 \\
\hline Resonant/output capacitor & 2 & 3 & 6 & 3 \\
\hline \multicolumn{5}{|l|}{ Seft-switching features } \\
\hline Main switches & $\begin{array}{l}\text { Turn on hard switching } \\
\text { turn off ZVT }\end{array}$ & $\begin{array}{c}\text { Turn on ZVS } \\
\text { turn off hard switching }\end{array}$ & $\begin{array}{c}\text { Turn on ZVS } \\
\text { turn off hard switching }\end{array}$ & $\begin{array}{c}\text { Turn on ZVS } \\
\text { turn off hard switching }\end{array}$ \\
\hline Auxiliary switches & & $\begin{array}{c}\text { Turn on ZVS } \\
\text { turn off hard switching }\end{array}$ & $\begin{array}{c}\text { Turn on ZVS } \\
\text { turn off hard switching }\end{array}$ & $\begin{array}{c}\text { Turn on ZVS } \\
\text { turn off hard switching }\end{array}$ \\
\hline Cost & Lower & High & Middle & Low \\
\hline Duty ratio limitation & $D<0.5$ & $D<0.5$ & $D>0.5$ & $D>0.5$ \\
\hline Turns ratio of transformer & 20 & 20 & 2.5 & 2.125 \\
\hline Control complexity & Middle (86\%) & High (90\%) & Higher (94.4\%) & Highest (96\%) \\
\hline $\begin{array}{l}\text { Conversion efficiency under } \\
\text { full load condition }\end{array}$ & Simplicity & Complexity & Complexity & Complexity \\
\hline Power level application & Middle power level & High power level & Lower power level & Low power level \\
\hline
\end{tabular}

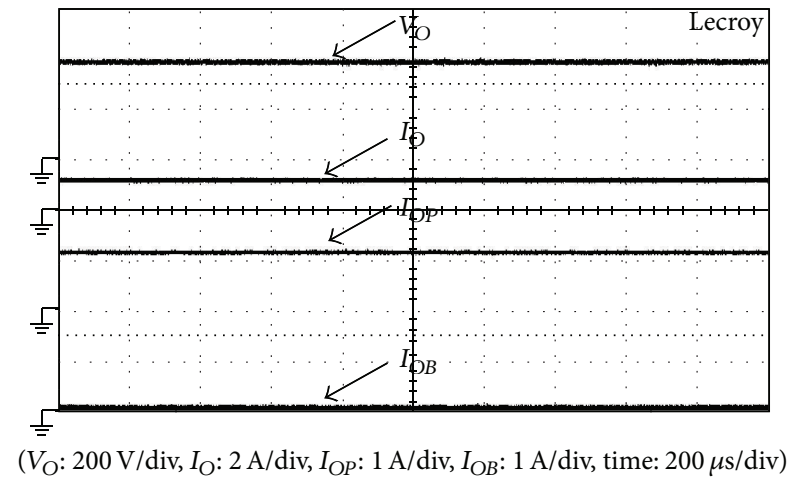

FIGURE 17: Measured voltage $V_{O}$, current $I_{O B}, I_{O P}$, and $I_{O}$ waveforms of the proposed PV power conversion system using the singlecapacitor snubber operated in mode VIII under $\left(P_{P(\max )}+P_{B(\max )}\right) \geq$ $P_{L}$ and $P_{\mathrm{PV}(\max )} \geq P_{L}$.

output voltage $V_{O}$ of boost converter with the single-capacitor snubber and boost type snubber are approximately the same as the one with hard-switching circuit. It reveals that the boost converter with the single-capacitor snubber and boost type snubber can yield a good dynamic performance.

According to the operational principles of the proposed converters with the single-capacitor snubber and the boost type snubber, switches of the proposed one with the singlecapacitor snubber have ZVT features at turn-off transition, while those switches with the boost type snubber have ZVS features at turn-on transition. Their conceptual waveforms are illustrated in Figures 11(b) and 11(c), respectively. Figures 12(a) and 12(b) show the current waveforms of switches and inductors in the interleaved coupled-inductor

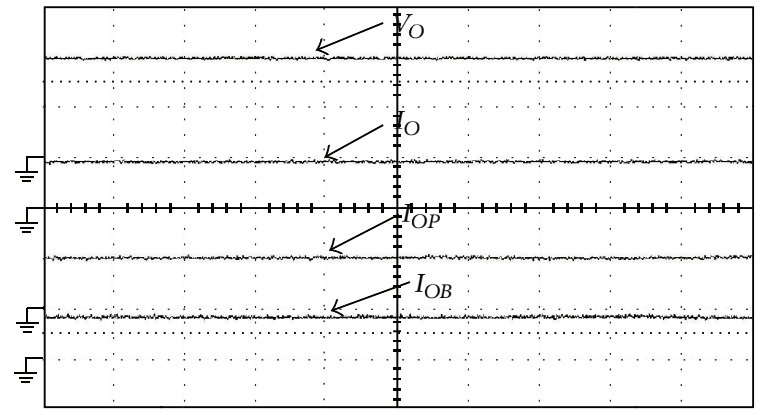

$\left(V_{O}: 200 \mathrm{~V} / \mathrm{div}, I_{O}: 2 \mathrm{~A} / \mathrm{div}, I_{O P}: 1 \mathrm{~A} / \mathrm{div}, I_{\mathrm{OB}}: 1 \mathrm{~A} / \mathrm{div}\right.$, time: $\left.100 \mu \mathrm{s} / \mathrm{div}\right)$

FIGURE 18: Measured voltage $V_{O}$, current $I_{O B}, I_{O P}$, and $I_{O}$ waveforms of the proposed PV power conversion system using the singlecapacitor snubber operated in mode VIII under $\left(P_{P(\max )}+P_{B(\max )}\right) \geq$ $P_{L}$ and $P_{\mathrm{PV}(\max )}<P_{L}$.

boost converter with hard-switching circuit and the singlecapacitor snubber, respectively. From Figure 12(b), it can be seen that when switch of one boost converter in the interleaved boost converter is turned on, the diode current $I_{D C}$ of the other boost converter in the interleaved one flows through the switch by the capacitor snubber. Therefore, the boost converter with the single-capacitor snubber will induce an extra turn-on switching loss. The key parameter values of the proposed interleaved boost converters with the singlecapacitor snubber and with the boost type snubber under full-load condition are listed in Tables 3 and 4, respectively. It can be found from Tables 3 and 4 that switching losses of the proposed converter with the single-capacitor snubber, compared with those of the proposed one with the boost 
TABLE 3: Parameter values of the boost converter with single-capacitor snubber under full-load condition.

\begin{tabular}{|c|c|c|c|}
\hline Parameters & Formulas & Calculation values & Practical values \\
\hline$I_{D B}$ & $\frac{(N+1) I_{\mathrm{O}}}{2(1-D)}-\frac{V_{\mathrm{PV}}}{L_{1}} D T_{S}$ & $38.87 \mathrm{~A}$ & $39.5 \mathrm{~A}$ \\
\hline$I_{D P}$ & $\frac{(N+1) I_{O}}{2(1-D)}+\frac{V_{\mathrm{PV}}}{L_{1}} D T_{S}$ & $54.47 \mathrm{~A}$ & $56 \mathrm{~A}$ \\
\hline$I_{D C}$ & $\frac{(N+1) I_{O}}{2(1-D)}+\frac{D V_{O} T_{S}}{L_{1}}-\frac{\left(V_{O}-V_{\mathrm{PV}}\right) T_{S}}{2 L_{1}}$ & $12 \mathrm{~A}$ & $63 \mathrm{~A}$ \\
\hline Switch stress $V_{D S(\max )}$ & $\frac{N V_{\mathrm{PV}}+V_{\mathrm{O}}}{N+1}$ & $53 \mathrm{~V}$ & $55 \mathrm{~V}$ \\
\hline Voltage across snubber capacitor $V_{C S}$ & $\left(V_{\mathrm{O}}+N V_{\mathrm{PV}}\right)$ & $1120 \mathrm{~V}$ & $1120 \mathrm{~V}$ \\
\hline Output diode stress & $\begin{array}{c}\left(V_{O}+N V_{\mathrm{PV}}\right) \\
V_{O}-V_{\mathrm{PV}}\end{array}$ & $1120 \mathrm{~V}$ & $1500 \mathrm{~V}$ \\
\hline Duty ratio $D$ & $N V_{\mathrm{PV}}+V_{\mathrm{O}}$ & 0.325 & 0.34 \\
\hline Snubber capacitor $C_{S}$ & $C_{S} \geq \frac{t_{s \text { off }}\left(N V_{\mathrm{PV}}+V_{\mathrm{O}}\right)}{(N+1)\left(V_{\mathrm{O}}+N V_{\mathrm{PV}}\right)^{2}} I_{D P}$ & $1.16 \mathrm{nF}$ & $10 \mathrm{nF}$ \\
\hline$T_{C C}$ & $\frac{C_{S} V_{D S(\max )}}{I_{D B}+I_{D C}}$ & $1.2 \mathrm{~ns}$ & $9.9 \mathrm{~ns}$ \\
\hline Switching loss of each switch at turn-on $P_{s \text { on }}$ & $\frac{1}{2 T_{S}} V_{D S(\max )}\left(I_{D B}+I_{D C}\right) t_{s \text { on }}$ & $5.86 \mathrm{~W}$ & $21.14 \mathrm{~W}$ \\
\hline Switching loss of each switch at turn-off $P_{s \text { off }}$ & & $0 \mathrm{~W}$ & $0 \mathrm{~W}$ \\
\hline Conduction loss of each switch $P_{\mathrm{SC}}$ & $\frac{1}{3 T_{S}}\left(I_{D P}^{2}+I_{D P} I_{D B}+I_{D B}^{2}\right) R_{\mathrm{ds}} t_{\mathrm{on}}$ & $28.58 \mathrm{~W}$ & $30.31 \mathrm{~W}$ \\
\hline Conduction loss of diode $P_{\mathrm{SCD}}$ & $V_{\mathrm{DF}} I_{\mathrm{O} 1(\mathrm{av})}=\frac{1}{2} V_{\mathrm{DF}} I_{\mathrm{O}}$ & $7.2 \mathrm{~W}$ & $7.5 \mathrm{~W}$ \\
\hline Forward drop voltage $V_{\mathrm{DF}}$ of output diode & & $\begin{array}{c}4.8 \mathrm{~V} \\
(2.4 \mathrm{~V} \times 2)\end{array}$ & $\begin{array}{c}4.8 \mathrm{~V} \\
(2.4 \mathrm{~V} \times 2)\end{array}$ \\
\hline$t_{\text {son }}$ & & $87 \mathrm{~ns}$ & $150 \mathrm{~ns}$ \\
\hline$t_{s \text { off }}$ & & $\begin{array}{c}103 \mathrm{~ns} \\
\left(P_{s \text { on }} \text { calculation }\right)\end{array}$ & $\begin{array}{c}500 \mathrm{~ns} \\
\left(C_{S} \text { calculation }\right)\end{array}$ \\
\hline$V_{\mathrm{PV}}$ & & $36 \mathrm{~V}$ & $36 \mathrm{~V}$ \\
\hline$V_{O}$ & & $400 \mathrm{~V}$ & $400 \mathrm{~V}$ \\
\hline$T_{S}$ & & $20 \mu \mathrm{s}$ & $20 \mu \mathrm{s}$ \\
\hline$I_{\mathrm{O}}$ & & $3 \mathrm{~A}$ & $3 \mathrm{~A}$ \\
\hline$N$ & & 20 & 20 \\
\hline$t_{\text {on }}$ & $D T_{S}$ & $6.5 \mu \mathrm{s}$ & $6.8 \mu \mathrm{s}$ \\
\hline$R_{\mathrm{ds}}$ & & $0.04 \Omega$ & $0.04 \Omega$ \\
\hline
\end{tabular}

type sunbber, increase by 20 30 W. Comparison of efficiencies among the discussed interleaved boost converters with different types of snubbers is illustrated in Figure 13. It shows that the boost converter with boost type snubber can yield the highest conversion efficiency than that with single-capacitor snubber from light load to heavy load. Conversion efficiencies of boost converters under full-load condition with boost type snubber and single-capacitor are $86 \%$ and $90 \%$, respectively. Since duty ratios of switches in two discussed PV power conversion systems are less than 0.5 , their turns ratios of coupled inductors have higher values. Therefore, a higher current flows through switches of the converter, resulting in a larger switching losses and conduction losses. Therefore, conversion efficiency of the converter in the two discussed PV power conversion systems can be further increased by reducing turns ratio of coupled inductor. Moreover, if the conducted resistances $R_{D S \text { (on) }}$ of switches in the converters are reduced, those in the two discussed PV power conversion systems will be increased. That is, a lower conducted resistance $R_{D S \text { (on) }}$ of switch can be chosen. In addition, two switches connected in parallel can be used for reducing the conducted resistance. By doing so, conversion efficiency of the proposed converter can be further increased by about 3 5\%.

Since the proposed boost converters with the singlecapacitor and boost type snubbers use the same control method, the measured results for MPPT and power management should be the same. Therefore, only the measured results of the proposed one with the single-capacitor snubber are shown in this paper. From the measured waveforms of voltage $V_{\mathrm{PV}}$, current $I_{\mathrm{PV}}$, and power $P_{\mathrm{PV}}$ under $P_{\mathrm{PV}(\max )}=$ $750 \mathrm{~W}$ shown in Figure 14, the tracking time of MPPT realized by the proposed converter with PV arrays as its 
TABLE 4: Parameter values of the boost converter with boost type snubber under full-load condition.

\begin{tabular}{|c|c|c|c|}
\hline Parameters & Formulas & $\begin{array}{l}\text { Calculation } \\
\text { values }\end{array}$ & Practical values \\
\hline$I_{D B}$ & $\frac{(N+1) I_{O}}{2(1-D)}-\frac{V_{\mathrm{PV}}}{L_{1}} D T_{S}$ & $38.87 \mathrm{~A}$ & $39 \mathrm{~A}$ \\
\hline$I_{D P}$ & $\frac{(N+1) I_{O}}{2(1-D)}+\frac{V_{\mathrm{PV}}}{L_{1}} D T_{S}$ & $54.47 \mathrm{~A}$ & $56 \mathrm{~A}$ \\
\hline Switch stress $V_{D S(\max )}$ & $\frac{N V_{\mathrm{PV}}+V_{\mathrm{O}}}{N+1}$ & $53 \mathrm{~V}$ & $55 \mathrm{~V}$ \\
\hline Output diode stress & $\left(V_{\mathrm{O}}+N V_{\mathrm{PV}}\right)$ & $1120 \mathrm{~V}$ & $1500 \mathrm{~V}$ \\
\hline Duty ratio $D$ & $\frac{V_{\mathrm{O}}-V_{\mathrm{PV}}}{N V_{\mathrm{PV}}+V_{\mathrm{O}}}$ & 0.325 & 0.34 \\
\hline Switching loss of each switch at turn-on $P_{s \text { on }}$ & & $0 \mathrm{~W}$ & $0 \mathrm{~W}$ \\
\hline Switching loss of each switch at turn-off $P_{s \text { off }}$ & $\frac{1}{2 T_{S}} V_{D S(\max )} I_{D P} t_{s \text { off }}$ & $7.43 \mathrm{~W}$ & $9.24 \mathrm{~W}$ \\
\hline Conduction loss of each switch $P_{\mathrm{SC}}$ & $\frac{1}{3 T_{S}}\left(I_{D P}^{2}+I_{D P} I_{D B}+I_{D B}^{2}\right) R_{\mathrm{ds}} t_{\mathrm{on}}$ & $28.58 \mathrm{~W}$ & $30.31 \mathrm{~W}$ \\
\hline Conduction loss of diode $P_{\mathrm{SCD}}$ & $V_{\mathrm{DF}} I_{\mathrm{O} 1(\mathrm{av})}=\frac{1}{2} V_{\mathrm{DF}} I_{\mathrm{O}}$ & $7.2 \mathrm{~W}$ & $7.5 \mathrm{~W}$ \\
\hline Forward drop voltage $V_{\mathrm{DF}}$ of output diode & & $4.8 \mathrm{~V}(2.4 \times 2)$ & $4.8 \mathrm{~V}$ \\
\hline$t_{s \text { on }}$ & & $87 \mathrm{~ns}$ & $100 \mathrm{~ns}$ \\
\hline$t_{\text {soff }}$ & & $103 \mathrm{~ns}$ & $120 \mathrm{~ns}$ \\
\hline$V_{\mathrm{PV}}$ & & $36 \mathrm{~V}$ & $36 \mathrm{~V}$ \\
\hline$V_{O}$ & & $400 \mathrm{~V}$ & $400 \mathrm{~V}$ \\
\hline$T_{S}$ & & $20 \mu \mathrm{s}$ & $20 \mu \mathrm{s}$ \\
\hline$I_{O}$ & & $3 \mathrm{~A}$ & $3 \mathrm{~A}$ \\
\hline$N$ & & 20 & 20 \\
\hline$t_{\text {on }}$ & $D T_{S}$ & $6.5 \mu \mathrm{s}$ & $6.8 \mu \mathrm{s}$ \\
\hline$R_{\mathrm{ds}}$ & & $0.04 \Omega$ & $0.04 \Omega$ \\
\hline
\end{tabular}

power source is about $80 \mathrm{~ms}$ from 0 to the maximum power of PV arrays. Figure 15 shows the measured waveforms of output voltage $V_{O}$ and current $I_{O B}$ and $I_{O}$ under $P_{L}=$ $350 \mathrm{~W}$, as the power management of the proposed PV power conversion system is operated in mode IV and $P_{B(\max )} \geq P_{L}$. From Figure 15, it can be seen that output voltages $V_{O}$ are sustained at $400 \mathrm{~V}$ and current $I_{B O}$ is equal to $I_{O}$. When the proposed PV power conversion system with the singlecapacitor snubber is operated in mode VI and $P_{\mathrm{PV}(\max )} \geq P_{L}$, measured waveforms of output voltage $V_{O}$ and currents $I_{O P}$ and $I_{L}$ under $P_{\mathrm{PV}(\max )}=700 \mathrm{~W}$ and $P_{L}=600 \mathrm{~W}$ are shown in Figure 16, illustrating that their output voltage are clamped at $400 \mathrm{~V}$ and current $I_{\mathrm{OP}}$ is equal to $I_{\mathrm{O}}$ and $P_{\mathrm{PV}}=600 \mathrm{~W}$.

The operational conditions of the proposed $\mathrm{PV}$ power conversion systems in mode VIII of $\left(P_{\mathrm{PV}(\max )}+P_{B(\max )}\right) \geq$ $P_{L}$ can be divided into two conditions: $P_{\mathrm{PV}(\max )} \geq P_{L}$ and $P_{\mathrm{PV}(\max )}<P_{L}$. The measured waveforms of output voltage $V_{\mathrm{O}}$, currents $I_{O P}, I_{O B}$, and $I_{O}$ under $P_{\mathrm{PV}(\max )}=700 \mathrm{~W}$ and $P_{L}=$ $500 \mathrm{~W}$ are shown in Figure 17. In this operational condition, current $I_{O P}$ is equal to $I_{O}$ and $I_{B}$ is equal to 0 . That is, the proposed boost converter with MPPT is used to supply power to load and PV arrays are not operated at MPP, while the proposed boost one with voltage regulation is shut down. When $P_{\mathrm{PV}(\max )}<P_{L}$, the measured output voltage $V_{\mathrm{O}}$ and currents $I_{\mathrm{OP}}, I_{\mathrm{OB}}$, and $I_{\mathrm{O}}$ under $P_{\mathrm{PV}(\max )}=400 \mathrm{~W}$ and $P_{L}=700 \mathrm{~W}$ are shown in Figure 18, illustrating that output voltage $V_{O}$ is still clamped at $400 \mathrm{~V}$ and $I_{O}=I_{O P}+I_{O B}$. The experimental results show that both of the proposed PV power conversion systems with the single-capacitor snubber and with boost type snubber can implement power management.

\section{Conclusion}

In this paper, an interleaved coupled-inductor boost converter with different soft-switching snubbers is proposed for PV arrays applications. To compare the performances of the proposed converter with the single-capacitor snubber or with the boost type snubber, MPPT algorithm, power management, and control design of the proposed PV power conversion system have been firstly described in detail. In addition, a perturbation-and-observation method is used to implement the MPPT algorithm. For further evaluating the performances and feasibilities of the proposed PV power conversion system, prototypes of PV power conversion system with different soft-switching snubbers and with specifications of $P_{\mathrm{PV}(\max )}=1.2 \mathrm{~kW}$ and $P_{V B(\max )}=1.2 \mathrm{~kW}$ have been built. Experimental results have shown that the proposed converter with boost type snubber can yield higher efficiency than the ones with the single-capacitor snubber and with hard-switching circuit, where the conversion efficiencies 
for converter with single-capacitor snubber and boost type snubber are $86 \%$ and $90 \%$ under full load, respectively. Therefore, the proposed interleaved coupled-inductor boost converter with the single-capacitor snubber is suitable for PV arrays applications with a lower cost, while the proposed one with boost type snubber is applied to PV arrays for a higher conversion efficiency power conversion system.

\section{References}

[1] J. L. Duarte, J. A. A. Wijntjens, and J. Rozenboom, "Designing light sources for solar-powered systems," in Proceedings of the 5th European Conference on Power Electronics and Applications, vol. 8, pp. 78-82, September 1993.

[2] U. Germann and H. G. Langer, "Low cost DC to AC converter for photovoltaic power con-version in residential applications," in Proceedings of the IEEE Power Electronics Specialist Conference (PESC'93), pp. 588-594, 1993.

[3] Y. Yu, Q. Zhang, B. Liang, X. Liu, and S. Cui, "Analysis of a single-phase Z-Source inverter for battery discharging in vehicle to grid applications," Energies, vol. 4, no. 12, pp. 22242235, 2011.

[4] S. B. Kjaer, J. K. Pedersen, and F. Blaabjerg, "A review of singlephase grid-connected inverters for photovoltaic modules," IEEE Transactions on Industry Applications, vol. 41, no. 5, pp. 12921306, 2005.

[5] P. J. Pérez, G. Almonacid, J. Aguilera, and J. de la Casa, "RMS current of a photovoltaic generator in grid-connected PV systems: definition and application," International Journal of Photoenergy, vol. 2008, Article ID 356261, 7 pages, 2008.

[6] J. Yoo, B. Park, K. An et al., "Look-ahead energy management of a grid-connected residential PV system with energy storage under time-based rate programs," Energies, vol. 5, article 4, pp. 1116-1134, 2012.

[7] A. D. Gerlando, G. Foglia, M. F. Iacchetti, and R. Perini, "Analysis and test of diode rectifier solutions in grid-connected wind energy conversion systems employing modular permanentmagnet synchronous generators," IEEE Transactions on Industrial Electronics, vol. 59, no. 5, pp. 2135-2146, 2012.

[8] F. A. Ramirezand and M. A. Arjona, "Development of a gridconnected wind generationsys-temwith a modified PLL structure," IEEE Transactions on Sustainable Energy, vol. 3, no. 3, pp. 474-481, 2012.

[9] T. M. van Breussegem and M. S. J. Steyaert, "Monolithic capacitive DC-DC converter with single boundary-multiphase control and voltage domain stacking in $90 \mathrm{~nm}$ CMOS," IEEE Journal of Solid-State Circuits, vol. 46, no. 7, pp. 1715-1727, 2011.

[10] V. P. Galigekere and M. K. Kazimierczuk, "Analysis of PWM Z-source DC-DC converter in CCM for steady state," IEEE Transactions on Circuits and Systems I, vol. 59, no. 4, pp. 854863, 2012.

[11] Z. Wang and H. Li, "A soft switching three-phase current-fed bidirectional DC-DC converter with high efficiency over a wide input voltage range," IEEE Transactions on Power Electronics, vol. 27, no. 2, pp. 669-684, 2012.

[12] H.-L. Do, "Improved ZVS DC-DC converter with a high voltage gain and a ripple-free input current," IEEE Transactions on Circuits and Systems I, vol. 59, no. 4, pp. 846-853, 2012.

[13] W. Qian, H. Cha, F. Z. Peng, and L. M. Tolbert, "55-kW variable $3 \mathrm{X}$ DC-DC converter for plug-in hybrid electric vehicles," IEEE
Transactions on Power Electronics, vol. 27, no. 4, pp. 1668-1678, 2012.

[14] S. L. Brunton, C. W. Rowley, S. R. Kulkarni, and C. Clarkson, "Maximum power point tracking for photovoltaic optimization using ripple-based extremum seeking control," IEEE Transactions on Power Electronics, vol. 25, no. 10, pp. 2531-2540, 2010.

[15] V. Agarwal, R. K. Aggarwal, P. Patidar, and C. Patki, "A novel scheme for rapid tracking of maximum power point in wind energy generation systems," IEEE Transactions on Energy Conversion, vol. 25, no. 1, pp. 228-236, 2010.

[16] M. Taherbaneh, A. H. Rezaie, H. Ghafoorifard, K. Rahimi, and M. B. Menhaj, "Maximizing output power of a solar panel via combination of sun tracking and maximum power point tracking by fuzzy controllers," International Journal of Photoenergy, vol. 2010, Article ID 312580, 13 pages, 2010.

[17] X. Weidong and W. G. Dunford, "A modified adaptive hill climbing MPPT method for photovoltaic power conversion systems," in Proceedings of the 35th Annual IEEE Power Electrons Specialists Conference, pp. 1957-1963, 2004.

[18] K. Kobayashi, H. Matsuo, and Y. Sekine, "An excellent operating point tracker of the solar-cell power supply system," IEEE Transactions on Industrial Electronics, vol. 53, no. 2, pp. 495-499, 2006.

[19] S. Subiyanto, A. Mohamed, and H. Shareef, "Hopfield neural network optimized fuzzy logic controller for maximum power point tracking in a photovoltaic system," International Journal of Photoenergy, vol. 2012, Article ID 798361, 13 pages, 2012.

[20] S. Jain and V. Agarwal, "A new algorithm for rapid tracking of approximate maximum power point in photovoltaic systems," IEEE Power Electronics Letters, vol. 2, no. 1, pp. 16-19, 2004.

[21] H. S.-H. Chung, K. K. Tse, S. Y. R. Hui, C. M. Mok, and M. T. Ho, "A novel maximum power point tracking technique for solar panels using a SEPIC or Cuk converter," IEEE Transactions on Power Electronics, vol. 18, no. 3, pp. 717-724, 2003.

[22] M. T. Billy Ho, S. H. Henry Chung, and S. Y. R. Hui, "An integrated inverter with maximum power tracking for gridconnected PV systems," in Proceedings of the 9th Annual IEEE Applied Power Electronics Conference and Exposition (APEC '04), vol. 3, pp. 1559-1565, 2004.

[23] D. Casadei, G. Grandi, and C. Rossi, "Single-phase single-stage photovoltaic generation system based on a ripple correlation control maximum power point tracking," IEEE Transactions on Energy Conversion, vol. 21, no. 2, pp. 562-568, 2006.

[24] Z. Liang, R. Guo, J. Li, and A. Q. Huang, "A high-efficiency PV module-integrated DC/DC converter for PV energy harvest in FREEDM systems," IEEE Transactions on Power Electronics, vol. 26, no. 3, pp. 897-909, 2011.

[25] H. Kim, C. Yoon, and S. Choi, "An improved current-fed ZVS isolated boost converter for fuel cell applications," IEEE Transactions on Power Electronics, vol. 25, no. 9, pp. 2357-2364, 2010.

[26] K. C. Tseng, C. C. Huang, and W. Y. Shin, "A high step-up converter with a voltage multiplier module for a photovoltaic system," IEEE Transactions on Power Electronics, vol. 28, no. 66, pp. 3047-3057, 2013.

[27] J.-M. Kwon and B.-H. Kwon, "High step-up active-clamp converter with input-current doubler and output-voltage doubler for fuel cell power systems," IEEE Transactions on Power Electronics, vol. 24, no. 1, pp. 108-115, 2009.

[28] Y. Zhao, W. Li, Y. Deng, and X. He, "Analysis, design, and experimentation of an isolated ZVT boost converter with 
coupled inductors," IEEE Transactions on Power Electronics, vol. 26, no. 2, pp. 541-550, 2011.

[29] F. Yang, X. Ruan, Y. Yang, and Y. Zhihong, "Interleaved critical current mode boost PFC converter with coupled inductor," IEEE Transactions on Power Electronics, vol. 26, no. 9, pp. 24042413, 2011.

[30] S. Dwari and L. Parsa, "An efficient high-step-up interleaved DC-DC converter with a common active clamp," IEEE Transactions on Power Electronics, vol. 26, no. 1, pp. 66-78, 2011.

[31] O. Hegazy, J. V. Mierloand, and P. Lataire, "Analysis, modeling, and implementation of amulti-device interleaved DC/DC converter for fuelcell hybrid electric vehicles," IEEE Transactions on Power Electronics, vol. 27, no. 11, pp. 4445-5558, 2012.

[32] W. Li, Y. Zhao, J. Wu, and X. He, "Interleaved high step-up converter with winding-cross-coupled inductors and voltage multiplier cells," IEEE Transactions on Power Electronics, vol. 27, no. 1, pp. 133-143, 2012.

[33] L. Weichen, X. Xiang, L. Wuhua, and X. He, "Interleaved high step-up ZVT converter with built-in transformer voltage doubler cell for distributed PV generation system," IEEE Transactions on Power Electronics, vol. 28, no. 1, pp. 300-313, 2013.

[34] M. Peipei, C. Henglin, S. Zheng, W. Xinke, and Q. Zhaoming, "Optimal design for the damping resistor in RCD-R snubber to suppress common-mode noise," in Proceedings of the 25th Annual IEEE Applied Power Electronics Conference and Exposition (APEC '10), pp. 691-695, 2010.

[35] R. T. H. Li, H. S.-H. Henry, A. K. T. Chung, and A .K. T. Sung, "Passive lossless snubber for boost PFC with minimum voltage and current stress," IEEE Transactions on Power Electronics, vol. 25, no. 3, pp. 602-613, 2010.

[36] B. Kim, H.-J. Ju, K.-C. Ko, and E. Hotta, "Active clamping circuit to suppress switching stress on a MOS-gate-structure-based power semiconductor for pulsed-power applications," IEEE Transactions on Plasma Science, vol. 39, no. 8, pp. 1736-1742, 2011.

[37] S. Y. Tseng, J. Z. Shiang, and Y. H. Su, "A single-capacitor turn-off snubber for interleaved boost converter with coupled inductor," in Proceedings of the 7th International Conference on Power Electronics and Drive Systems (PEDS '07), pp. 202-208, 2007.

[38] S. Y. Tseng, C. L. Ou, S. T. Peng, and J. D. Lee, "Interleaved coupled-inductor boost converter with boost type snubber for PV system," in Proceedings of the IEEE Energy Conversion Congress and Exposition (ECCE '09), pp. 1860-1867, 2009. 

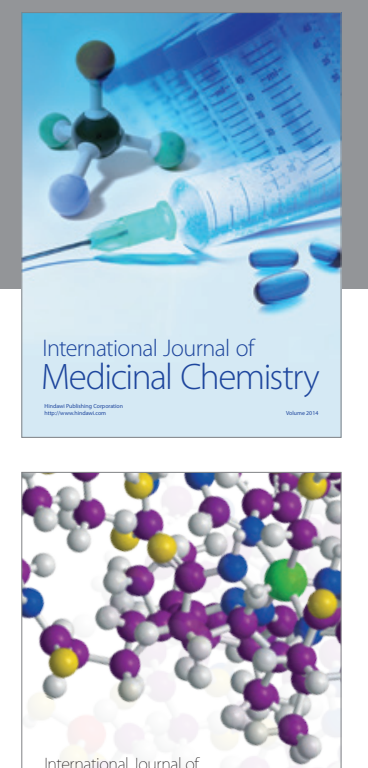

\section{Carbohydrate} Chemistry

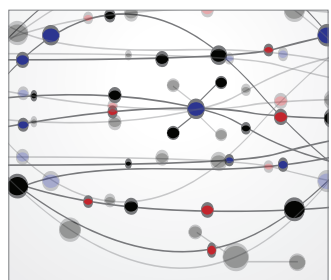

The Scientific World Journal
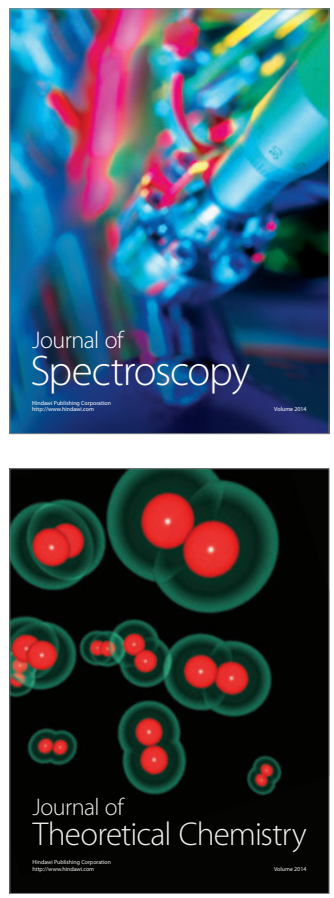
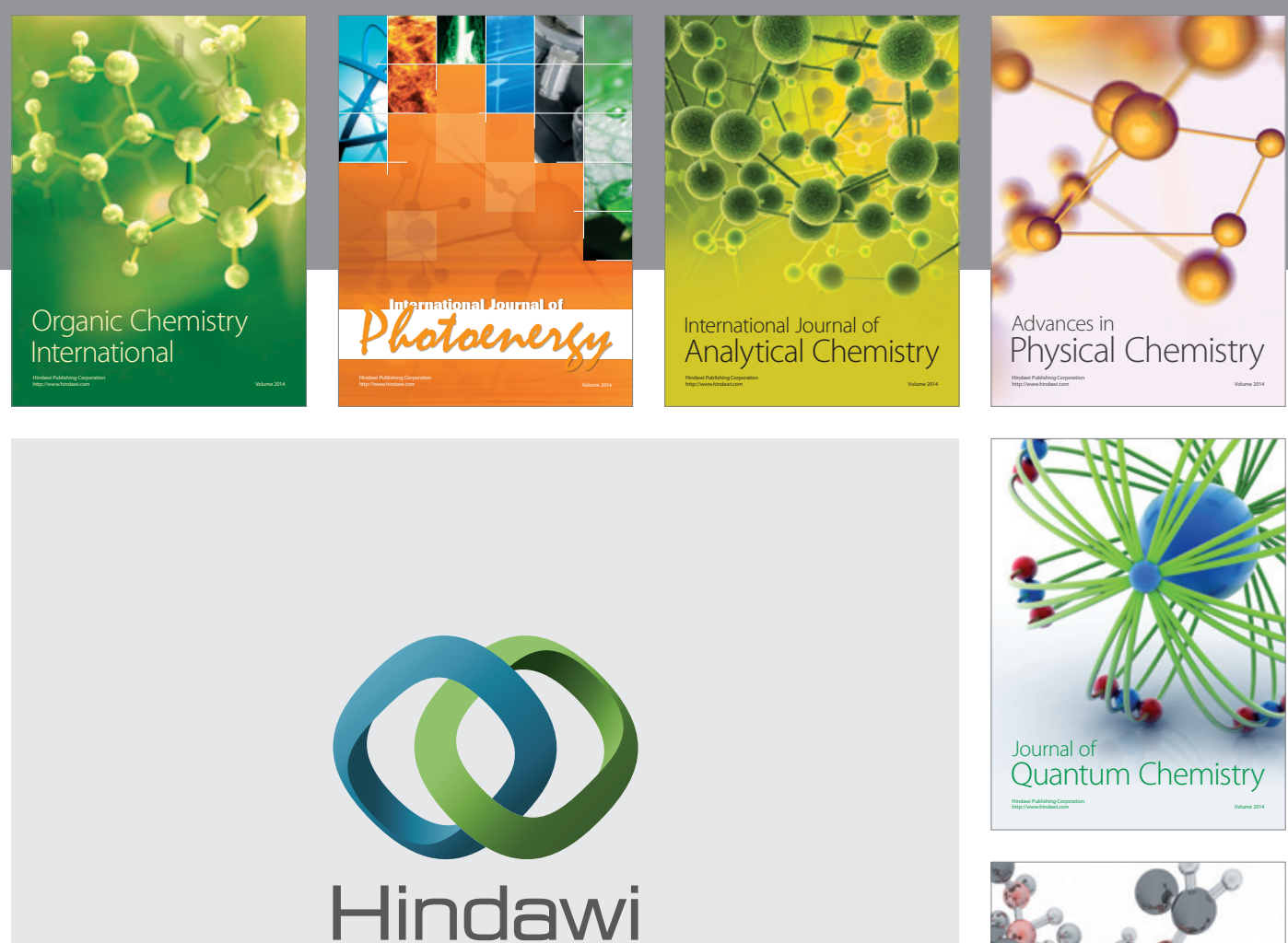

Submit your manuscripts at

http://www.hindawi.com

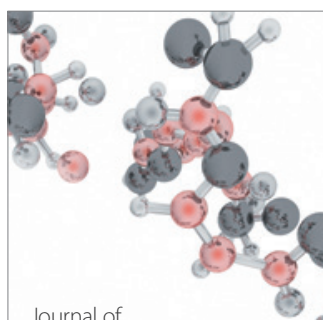

Analytical Methods

in Chemistry

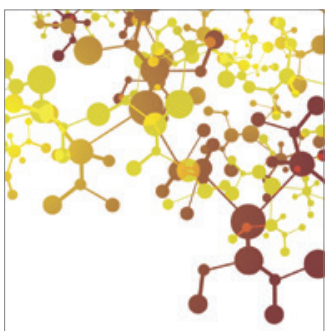

Journal of

Applied Chemistry

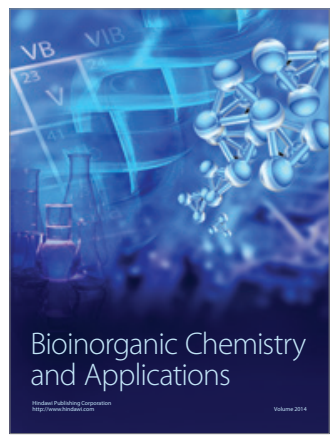

Inorganic Chemistry
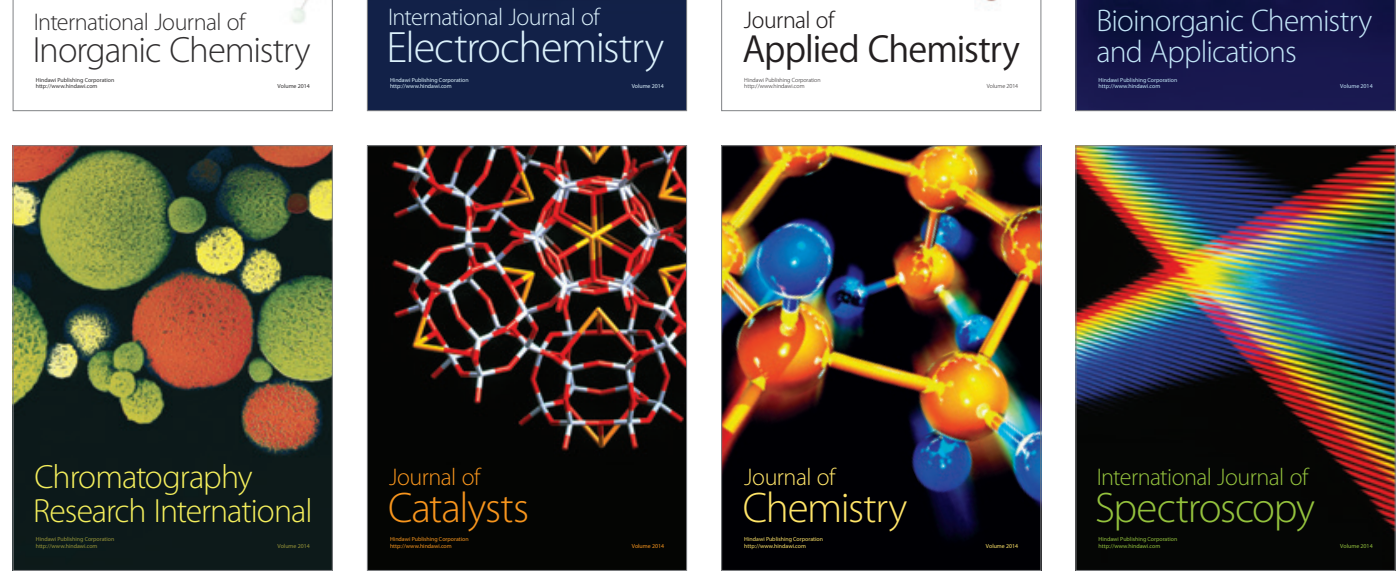